Review

\title{
Challenges and Strategies for Employee Retention in the Hospitality Industry: A Review
}

\author{
Bilqees Ghani ${ }^{1}$, Muhammad Zada ${ }^{2, *}$, Khalid Rasheed Memon ${ }^{3}$ (D), Rezwan Ullah ${ }^{4}$, Afraseyab Khattak ${ }^{5}$, \\ Heesup Han ${ }^{6, *(\mathbb{D})}$, Antonio Ariza-Montes ${ }^{7}$ (D) and Luis Araya-Castillo ${ }^{8}$ (D)
}

1 College of Business Management, Institute of Business Management, Karachi 75190, Pakistan; bilqees.ghani@iobm.edu.pk

2 Business School, Henan University, Kaifeng 475001, China

3 Graduate School of Business, Universiti Sains Malaysia, George Town 11800, Malaysia; khalidilm@hotmail.com

4 School of Management and Economics, Beijing Institute of Technology, Beijing 100081, China; rezwanullah1990@yahoo.com

5 Institute of Business and Management Sciences, University of Agriculture, Peshawar 53130, Pakistan; siab4@aup.edu.pk

6 College of Hospitality and Tourism Management, Sejong University, Seoul 05006, Korea

7 Social Matters Research Group, Universidad Loyola Andalucía, C/Escritor Castilla Aguayo, 4, 14004 Cordoba, Spain; ariza@uloyola.es

8 Facultad de Economía y Negocios, Universidad Andres Bello, Santiago de Chile 7591538, Chile; luis.araya@unab.cl

* Correspondence: mzada@henu.edu.cn (M.Z.); heesup.han@gmail.com (H.H.)

check for updates

Citation: Ghani, B.; Zada, M.;

Memon, K.R.; Ullah, R.; Khattak, A.; Han, H.; Ariza-Montes, A.; Araya-Castillo, L. Challenges and Strategies for Employee Retention in the Hospitality Industry: A Review. Sustainability 2022, 14, 2885. https:// doi.org/10.3390/su14052885

Academic Editors: Peter Holland and Renee Paulet

Received: 28 December 2021

Accepted: 21 February 2022

Published: 2 March 2022

Publisher's Note: MDPI stays neutral with regard to jurisdictional claims in published maps and institutional affiliations.

Copyright: (C) 2022 by the authors. Licensee MDPI, Basel, Switzerland. This article is an open access article distributed under the terms and conditions of the Creative Commons Attribution (CC BY) license (https:// creativecommons.org/licenses/by/ $4.0 /)$.

\begin{abstract}
Despite the issues that the hospitality industry encounters in retaining talented employees, little attention has been paid to the development of retention strategies, resulting in poor organizational performance and sustainable growth. The current study, therefore, aims to review and discuss the employee retention strategies in the hospitality industry in order to keep talented employees for a longer period of time. The study is based on past literature and peer-reviewed articles published between 2010 and 2020. The databases Web Knowledge, Emerald, Google Scholar, and Science Direct were used to find the relevant papers using the key words such as "Hospitality Industry", "employee retention", "employee turnover", and "employees". The findings of this study suggest that employee retention is contingent on employee satisfaction, which is comprised of four factors: sustainable positive work environment; sustainable growth opportunities; sustainable \& effective communication; and sustainable \& effective recruitment and selection practices. The paper contributes to a comprehensive review of the literature on employee retention strategies in the hospitality context. The study proposes a model for the hospitality industry to revamp its recruitment and selection practices in order to retain its employees. Furthermore, the study provides a focused directions that will aid in the establishment of employee retention strategies and practices. It was concluded that satisfied employees are less likely to leave their current job, while unsatisfied employees are expected to leave their current job for a better career opportunity. Managerial implications were also discussed.
\end{abstract}

Keywords: comprehensive literature review; recruitment and selection; HR practices; employee retention; hospitality industry

\section{Introduction}

It has been acknowledged that people are a significant source of competitive advantage; organisations adopt numerous policies and procedures in order to retain their talented employees for a long time. As a result, employee retention has emerged as one of the key drivers for organizational success, alongside reducing unnecessary expenses and improving employees' motivation and capabilities [1]. Employee retention, on the other hand, has been identified one of the biggest challenges in the 21st century, particularly in the 
hospitality industry. Because the hospitality industry is continuously dealing with the problem of shifting a workforce, retention is an ongoing and ever-evolving endeavor to keep its skilled personnel [2,3]. It is implied that environmental and social activities in the hospitality industry contribute a lot more to revamping the HR activities, especially when it comes to retaining the employees. Through sustainable HR, the hospitality industry can better address its employees issues and their employment concerns, which ultimately help them to develop a positive attitude and a strong commitment towards longer staying [4]. It is expected that in the next 10 years, the hospitality industry will offer around 72 million jobs [5]. The hospitality industry, therefore, found a most dynamic and globally growing industry, plays a significant role in the economic and social development. Furthermore, it is a significant component in boosting economic growth by attracting millions of foreign visitors annually. The spectacular development of this industry is necessary for the growth of the economic health, since it's may create great employment opportunities and attract foreign investment into the country. Research shows that human resource management is one of the most important organizational functions that influences employee retention [6,7]. Organizations that do not focus on their human resource practices are more likely to lose their skilled and trained employees, in turn they bear twice cost on account of financial and operational ineffectiveness [8]. Human resource management practices such as compensation management, recruitment and selection, training and development, performance appraisal and management, and benefits administration shape employees' overall experience in an organization. Human resource practices that contribute to employee growth and development increase employee retention. Additionally, effective human resource management practices not only ensure the desired skills, abilities, and knowledge of employees but also employee motivation. It also helps to reduce turnover, increase productivity, and improve employees' performance, job satisfaction, and overall organizational performance [9]. The global turnover rate is increasing, and employee retention has become a global challenge for the industry like hospitality industry [10]. Research highlights that production and service are major constituents of the hospitality industry. This shows that rendering services to customers is contingent on employees. Hence, the primary objective of the hospitality industry is to manage their employees effectively and keep them on staff in order to get the best out of them [11]. From this point of view, keeping employees longer and gaining an advantage from them is an important task, which is perhaps the biggest challenge for the hospitality industry [12]. The study, therefore, aims to review and suggest the best retention strategies, particularly in the realm of the hospitality sector. In line with the discussion, the study specified various reasons/root causes from the existing literature contributing to the high staff turnover rate in the hospitality industry, which are listed in Table A1, shown in Appendix A.

\section{Problem Statement}

Research posits that retaining employees, especially in the hospitality industry, is highly challenging due to varying demand and job-hopping by a number of employees from time to time [11]. The employees working in the hospitality industry are supposed to deal with visitors and customers globally on a day-to-day basis, which causes stress. As a result, their satisfaction level may be reduced, and they may be unwilling to stay there $[13,14]$. The lack of growth and development is highlighted as the most discussed cause of the high turnover rate globally, particularly in the hospitality industry. Research highlights that the management of the hospitality industry still focuses on old traditional methods to retain employees, i.e., one-way communication and feedback, where employees cannot share their long-term plans with their respective bosses and cannot get feedback or suggestions for their career development. In view of the 21st century, such methods are no longer effective to reduce the employee turnover rate [15].

Although the hospitality industry continue to put in efforts to maintain proper staffing levels, issues relating to retaining employees continue to surface. Alongside the challenges, there are a series of employment opportunities in the hospitality industry $[16,17]$. Of 
these, employee retention is one of the most demanding challenges around the globe. The research highlighted that the hospitality industry is encountering difficulty in maintaining the balance between the supply and demand of human capital [18]. Employee turnover is expensive, as it accounts for around $40 \%$ of total expenses. In order to control labor expenses or labor costs, this industry needs to retain its employees.

\section{Research Questions}

In today's world, where the hospitality industry is encountering an increasing number of customer demands and expectations, keeping employees who are committed with their work and produce quality customer service has become its ultimate goal [19]. Previous studies have focused on a single aspect of human resource management practices that can contribute to the performance of the hospitality industry. However, research on human resource management practices has advanced significantly, but little research has been done about the challenges and prospects for employee retention strategies [20,21]. This study, therefore, seeks to review and analyze the role of HR management in formulating and implementing retention strategies in the hospitality industry, this leads to our first research question:

RQ1. What is the role of the HR department in formulating and implementing retention strategies in the hospitality industry?

Employee retention has emerged as a critical strategic concern for the global hospitality business. Researchers and academics are increasingly worried about employee retention in the hospitality industry [2]. A poor retention rate undermines the organization's competitiveness, operational and financial effectiveness, and profitability. Low retention is related with a loss of human capital, which threatens the organization's profitability and performance. Organisations that understand the causes of employee turnover can implement the measures to increase their competitiveness and profitability. [22] To establish effective retention strategies, the root causes of the high turnover and low retention rates must be investigated. According to a past study, the causes of high turnover vary from organization to organization, which is why there is no general or universally accepted cause for the high turnover rate in the hospitality industry [23]. Researchers linked high turnover with low compensation, limited growth opportunities, a poor work environment, and long working hours [24]. According to a previous study, if the main cause of the low retention rate in the hospitality industry is unknown, developing effective strategies will be extremely challenging [25]. Thus, the second research question of this paper is to study the challenges faced by the hospitality industry in retaining its employees.

RQ2. What are the most common reasons for the high turnover rate in the hospitality industry?

Furthermore, in the service industry, frontline employees need to be the center of management concern because they serve customers, and customer satisfaction is a key component in the overall success of the service business [26]. Investment in employees (e.g., revamping recruitment and training practices and compensation) is more necessary than setting profit goals. Since, the hospitality industry is a customer-oriented industry, serving employees to be satisfied must be its first priority [27]. A past study stated that retention should be an integral part of the overall talent management strategy [28]. This is why the hospitality industry needs to satisfy its employees by implementing different retention strategies to prevent and reduce high turnover rates. These strategies will help the organization to encourage employees to stay with them for a longer period of time. Additionally, it is believed that if the right strategies are proposed and implemented in this industry, they will help the industry to accomplish its goals and bring organizational success. Conversely, the existing literature offers extrinsic as well as intrinsic employee retention policies and strategies, yet the retention rate remains quite low [29]. Extensive literature suggests that good compensation packages, effective growth opportunities, training, and development can all contribute to the retention of employees. The third research objective of this paper is to suggest strategies that can help the hospitality industry reducing its turnover rate $[30,31]$. 
RQ3. What are the interventions that can help improving the retention strategies in the hospitality industry?

\section{Purpose of the Study}

This study aims to review and identify the challenges and strategies regarding employee retention in the capacity of hospitality industry. The primary goal of the hospitality industry is to provide great customer service. In order to increase its contribution to economic development and survive in a competitive market, the hospitality industry needs to invest in its human capital. In the service industry, employees' direct interaction with customers adds a lot to the competitive advantage of a company.

\section{Literature Review}

A past study by the Professor of Business Administration at Harvard Business School [32] defined human resource management as one of the most important management activities in decision-making, and in all activities that influence the nature of life (the employeeagency relationship) [33]. Human resource management is also defined as a powerful term which is used to define the principles, philosophies, and practices that follow the leadership of people in an organization. In addition, human resource management is defined as all of the activities related to the workplace and employee management. According to Armstrong, the concepts of human resources and human resource management have been completely replaced by human resource management, which is the process of managing employees and their needs in organizations. Furthermore, human resource management has been defined as the process of recruitment and selection, performance management and appraisal, the wellbeing of workers, training and development, and relationships with employees aiming to achieve the organizational goals [32,34].

\subsection{Employee Retention}

The term "retention" can be defined as a systematic effort to create and improve an environment that continues to encourage employees to work while implementing policies and practices that suit their diverse needs. Employee retention is the process of retaining employees, or encouraging them to stay with the company for as long as possible. Employee retention is "a method by which companies maintain an efficient workforce and meet operational requirements" [35]. It is a method of encouraging employees to stay with the organization, or to stay with the organization until a project is completed [36]. According to [16], human resources are a systematic effort to create and improve an environment that encourages employees by promoting policies and practices that meet their diverse needs.

\subsection{Employee Turnover}

There are two types of staff turnover: voluntarily and involuntarily. involuntary turnover can be defined as the employees deliberately being terminated by employer or employees are being forced to resign their job due their undesired or low performance. If the person can make a personal decision to leave the company, then this is known as "voluntary turnover" (e.g., to take the best opportunity to work in another organization). A termination that is not officially issued by the employee is voluntary. This type of turnover is consistent with the controls and settings of the employees alone, not the management. Employees who resign on their own are aware of their current job and employment opportunities in other, more successful organizations. Employees who leave the company tend to be more skilled and talented than others, as they take better jobs. On the other hand, the employees who leave may not reveal the real reason or the purpose of their leaving. For this reason, most studies of retention or turnover are on the subject of voluntary, rather than involuntary, turnover.

The hospitality industry is recognized as one of the elements of the service sector that focuses on customer leisure activities and customer satisfaction, rather than more basic needs. This is why customer experience that leads to customer satisfaction is the top priority 
in this industry. The hospitality industry is highly dependent on its employees; therefore, it is a very labor-intensive industry in which the growth of the industry has a strong impact on employment [37]. The nature of the services—such as event planning, lodging, and serving food and beverages-provided by this industry requires skilled employees who directly interact with customers and represent the organization. In general, the industry is composed of four major categories: restaurants, travel, tourism, and accommodation. These four categories are further divided into tea shops, drink shops, cafes, bars, clubs, resorts, and hotels.

Globally, the hospitality industry is facing a very serious challenge in the form of its low retention rates. This research examines and discusses the effects of the factors propping up the high turnover rate in the hospitality industry. These factors arise in organizations that influence employees to quit their jobs. There are several aspects that, surprisingly or simultaneously, can contribute towards such a situation [38]. Data from around the world shows that high turnover is a major challenge in the hospitality industry [6]. It is believed that high turnover usually leads to business failure, a lack of motivation, and the poor performance of the organization $[39,40]$.

In recent years, the economy has changed dramatically as a result of globalization, in which organizations are judged against international standards and best practices. With expansion, workforce diversity, and the new nature of organizations, the focus is on people. As a result, organizations have found that these changes had a huge impact on their performance, and that the key to quality transfer was the organization's ability to motivate employees to participate [41]. Because the hospitality industry needs to achieve results through its employees, the focus should be on motivating and caring for people through HR practices such as evaluation, regular feedback, and continuous support, as well as sustainable development.

Globally, researchers have the same opinion regarding the role of human resources in the success of an organization. They recognize human resources as the most valuable resource in the organization [2]. Successful organizations create their competitive advantage through their employees because they know how to satisfy their employees and how to unleash the human potential of the organization [42]. From the perspective of these circumstances, several factors can combine to further complicate retention. According to SABMiller, one of the world's leading and most recognized breweries, their human resources set them apart from their competitors. Moreover, their employees' commitment and passion have helped SABMiller to build its recognition among customers. This shows that, along with attracting and developing employees, it is also very important to acknowledge their contribution. This means that employee retention is a serious concern for most large companies, especially in the service sector.

The hospitality industry offers services and caters to its customers through its employees, which is why this industry needs to invest in its employees [43]. Being a serviceoriented industry, the hospitality industry is human-intensive, and in order to drive success and provide better customer service, having an efficient workforce is necessary. Effective human resource management (HRM) is one of the main approaches, especially in recruitment, which is critical to the success of the hospitality industry. Additionally, in order to invest in employees, it is necessary to implement the best HRM practices and develop the skills of employees. Recruitment and selection is the first function of human resource management, acting as the backbone of any organization [2]. Recruitment and selection is the process of searching for and selecting the best fit for the organization. This is why the most important thing for the hospitality industry is to encourage potential career seekers to join this industry and make it their first preference. Recently, the industry has started to focus on hiring from university placement programs, but they are not successful in retaining these fresh graduates because their internal culture does not fulfil the needs of these fresh graduates. There is no focus on the post-hiring promise. This shows that their recruitment and selection process is not effective, which is what is causing the high turnover rate in this industry. 
Table A2, depicted in Appendix A, shows the ways in which human resource management practices such as administrative policies, compensation and benefits, performance management, recruitment and selection, and growth and development influence employee retention. Furthermore, in order to analyze the essence and relationships of the study's key themes and variables, content analysis was carried out as shown in Table A3 (Appendix A).

\section{Materials and Methods}

\subsection{Research Design}

The study used the literature review method to answer the formulated research questions and achieve the set objectives. The study included literature from March 2010 to 2020 from the following databases: Web Knowledge, Emerald, Google Scholar, and Science Direct. The study used the key terms such as "hospitality Industry", "employee retention", "employee turnover", and "employees" to search and identify the relevant papers. Continuing on from this, we added a filter to collect all studies published between 2010 and 2020. First, we collected the total number of published studies. In the second phase, we excluded articles based on eligibility criteria, title, and relevancy. In the third step, we selected the final sample of 48 articles, based on further reading of the complete article. The selected research papers included a broad range of sample sizes. Comprehensive literature reviews were also included, in which the sample size was based on past literature. Most of the studies considered middle- and lower-level employees, whereas various studies used random sampling techniques to estimate the population value.

\subsection{Search Outcome}

In total, 163 papers were found from 3 databases. By applying the inclusion and exclusion criteria over a 10-year period (2010-2021), 77 studies were excluded, and the remaining 86 papers were accessed and reviewed at their full length. Based on the classification of the studies, a PRISMA (Figure 1) was developed and is depicted below. A total of 48 papers were selected. Before 2010, the relevant studies were much more focused on the determinants of retention, instead of challenges and strategies. The objective of the current study, however, is to seek out retention strategies. The study, therefore, included papers from 2010 to 2020. Table 1 shows the inclusion and exclusion criteria for the studies.

Table 1. Exclusion and inclusion criteria.

\begin{tabular}{cc}
\hline Inclusion Criteria & Exclusion Criteria \\
\hline Peer Reviewed Journals & \\
Papers published in English & \\
Papers published between 2010-2021 & \\
Articles related to Employee Retention & Non-peer reviewed \\
Primary, Secondary data Research & jour \\
Literature Reviews & All papers published before 2010 \\
Qualitative, Quantitative Researches & Papers published in other languages \\
Full Text Available & Duplicated Work \\
Observational Studies & Papers that do not focus on Employee \\
Original Research Papers & \\
Articles relevant to both employee
\end{tabular}

\subsection{Search Method}

Three electronic databases were used for the literature searches: Google Scholar, Science Direct, and Emerald. The following keywords were included in the searches: "retention", "turnovers", "employee retention", "employee turnover", "hospitality industry", "service sector", "retain", "hospitality", "intention to leave", "employee management", "retention rate", "turnover rate", "leave", "stay", and "hospitality employees". These keywords were used to locate research papers that have examined the factors affecting employee retention in the hospitality industry or the intention of employees to leave the 
hospitality industry. In order to consider or examine only relevant and updated papers, the time frame of the research study was restricted to the period of 2010 to 2021.

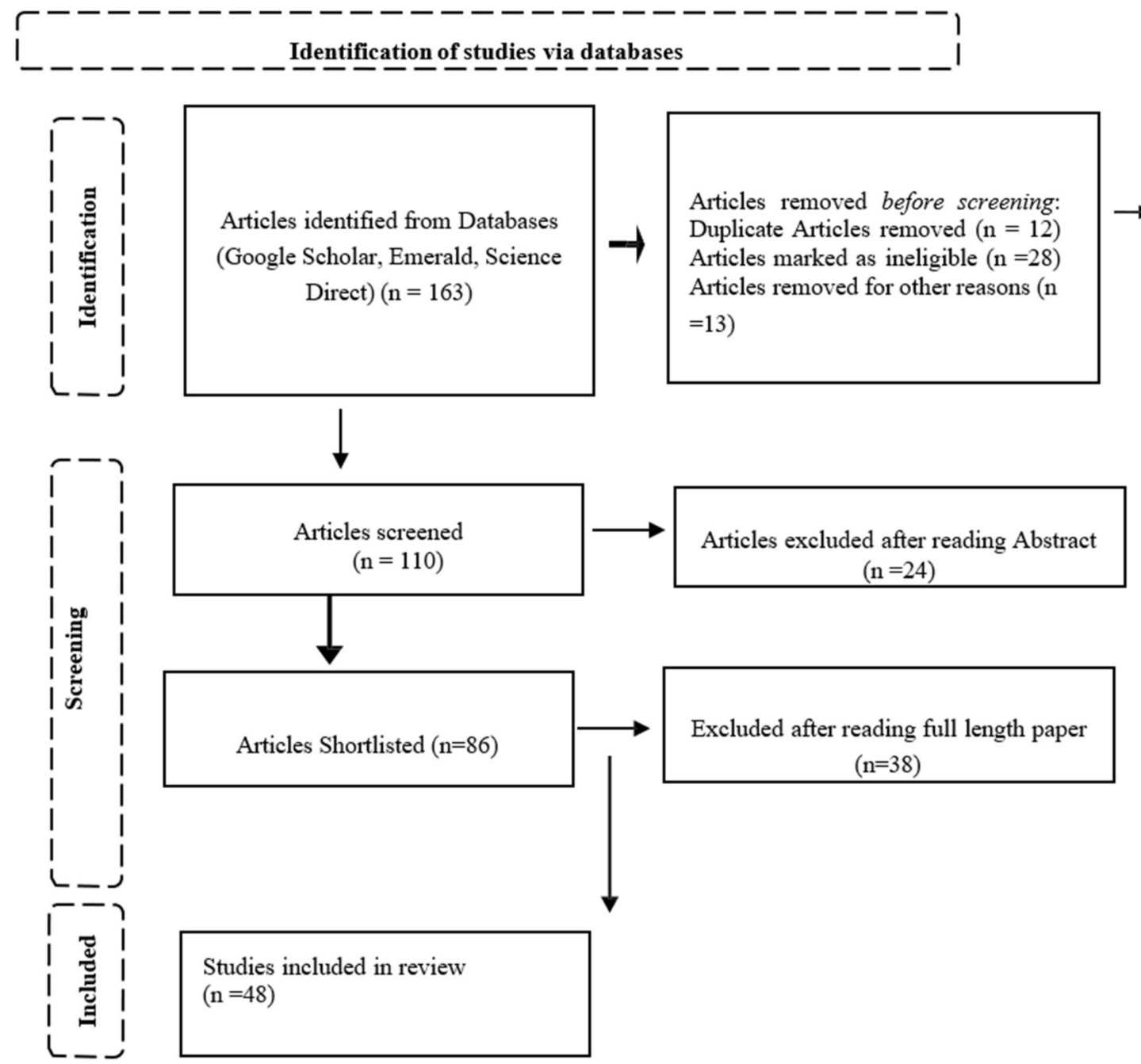

Figure 1. Prisma flow diagram (flow diagram of the literature search and selection process).

\section{Results and Findings}

The results were achieved by reviewing and synthesizing all of the relevant studies. The study covered around 48 studies based on the inclusion criteria. Based on the analysis of identified theories and relevant research on sustainable HR practices, the study provided new insights into employee retention and how to reduce the high turnover rate in the hospitality industry. The findings suggest that the retention rate in the hospitality industry is highly contingent on employees' level of satisfaction, which is composed of four factors: sustainable and positive work environment, sustainable growth opportunities, sustainable and effective communication, and sustainable and effective recruitment and selection. Figure 2, showing the identified theories and factors that can help to retain the employees.

\subsection{Equity Theory}

This theory, from John Stacey Adams, claims that people not only consider the reward that they receive in return for their performance or efforts but also what other people are receiving [44-46]. They consider the relationship between their reward and the rewards of other people. If we implement this theory in an organizational context, we can conclude that employees compare their efforts—such as qualification, experience, performance, com- 
petence, and skills—and rewards—such as appraisal, promotion, bonuses, salary increase, and recognition-to other employees' efforts and rewards. When employees perceive disparities or differences in the rewards that they are receiving relative to other employees, conflict is created. These employees have a difficult time receiving their expected or perceived fair reward [47,48]. Equity theory is based on the following three main components or assumptions.

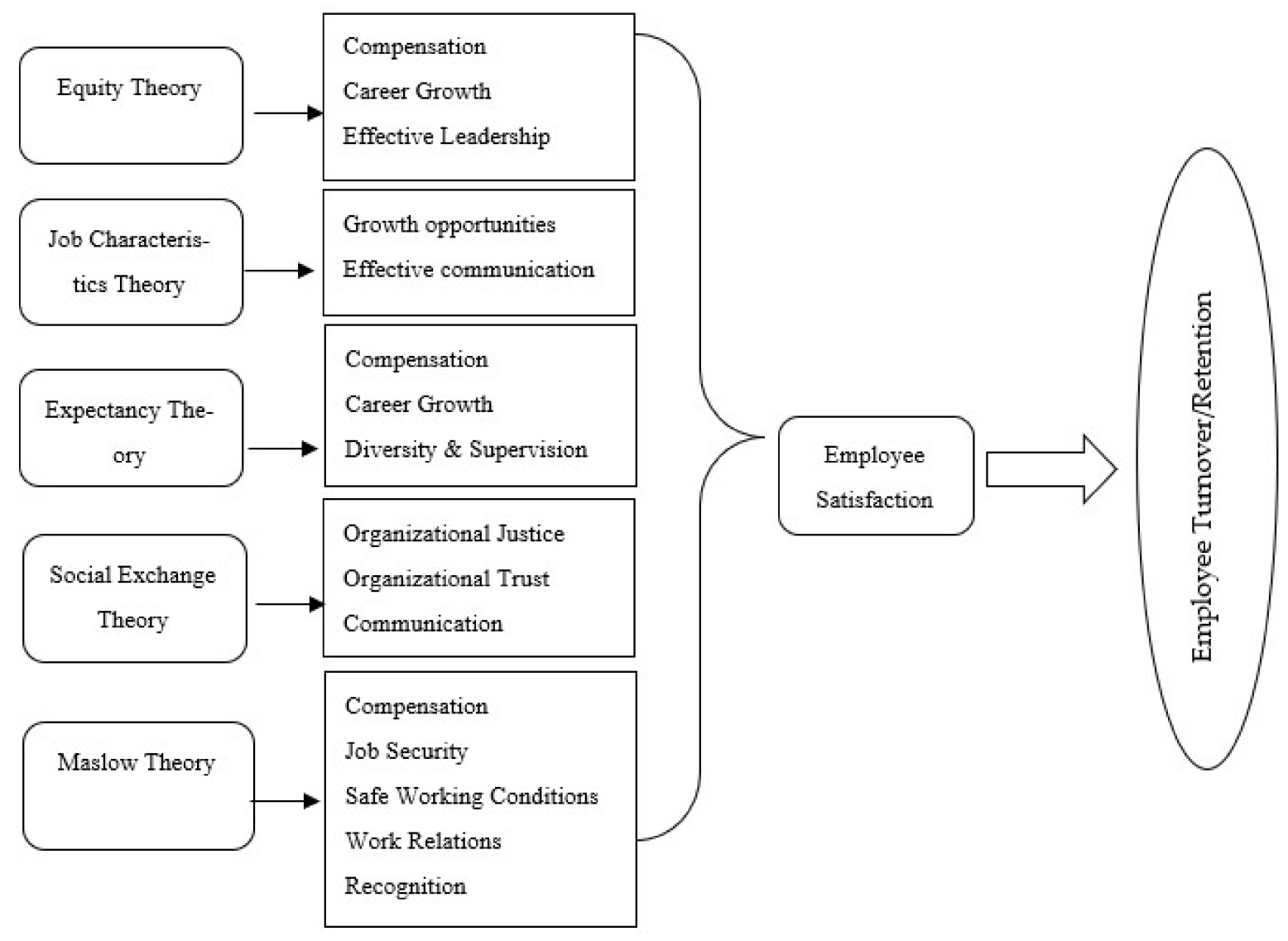

Figure 2. Model of theories which are relevant to employee retention.

People perceive rewards as fair or equitable according to their own beliefs or expectations for their efforts. People compare their reward with the reward of other employees according to their perception of their contribution. When people realize that their contributions or efforts are not equitable compared to those of other people, they act to contribute more or to improve their performance.

This theory helps managers to create a positive association between the performance and rewards of employees. According to this concept, we can assume that an employee who leaves an organization due to biased, unfair, and inequitable treatment develops these feelings when they do not receive a fair reward for their contributions or efforts [49-51]. These feelings can be based on actual inequity as well as perceived inequity. This is why it is challenging for organizations to develop reward systems such as compensation, growth opportunities, and appraisals that are perceived as equitable and fair by employees. In addition to this, it is also very important to distribute rewards according to the actual performance of employees [52]. Employees reduce their contribution and efforts, start to search for better opportunities in the job market, and restrict their work output when they perceive that there is an imbalance in their reward compared to other employees' rewards. Consequentially, this behavior of employees leads to high turnover and lower productivity. 


\subsection{Job Characteristics Theory}

The approach of this theory is to develop jobs that satisfy and motivate employees. This theory suggests some features that can help managers make the jobs of their subordinates attractive [53,54]. The theory proposes that intrinsic motivation can be experienced by employees if their job produces three important psychological factors, including the personal responsibility of the employee, the meaningfulness of work, and the contribution of the employee [55]. Employees are intrinsically motivated when the job is meaningful and the consequences of the job are considered the personal responsibility of the employee. This helps the employee to understand that their contribution directly affects the overall effectiveness of the organization [56-58]. To sum up this concept, we can say that a job should be designed in a way that creates an experience of responsibility, meaningfulness, and knowledge of the consequences of the contribution. Skill variety, i.e., different activities in a job using different skills; task identity, i.e., the degree to which employees identify the outcome of their efforts; and task significance, i.e., the impact of the job on other people, are three main elements to the creation of an experience of feeling intrinsically motivated.

Autonomy and feedback are the remaining two factors required to make a job meaningful. An employee needs substantial freedom and continuous feedback on their work. If we use this theory for the retention of employees, we can see that this model helps the employee to consider their work as being meaningful, which motivates them to take responsibility and contribute through better performance. This automatically leads to employee satisfaction, which is essential to employee retention. Thus, this theory suggests that, along with other factors, feedback is also very critical for reducing turnover. A proper feedback system can be implemented through effective communication in the organization.

\subsection{Expectancy Theory}

This theory claims that people behave in a certain way due to the expected outcome. According to Victor Vroom, behavior is reinforced by consequences. In light of this theory, we can say that employees behave in a certain way based on the expected consequences. For example, employees will perform better if they are rewarded, but the reward needs to be meaningful. This theory helps managers to identify factors that affect employee motivation and choose among various alternatives [59,60]. In the workplace, employees exchange their performance, efforts, or contributions for salary, compensation, or any other reward. This input may also include the qualifications, work experience, and skills of employees. Here, the important outcomes exchanged for inputs are cash and non-cash benefits, titles, and recognition.

Employees put more effort in when they know they will receive a reward for their efforts. The behavior of task accomplishment is motivated by the type of reward or value that the employee receives. Porter explained this behavior in terms of the relationship between the effort and the performance of the employee. He stated that, in the prediction of the performance of an employee, this relationship acts as a moderator [61]. Furthermore, employees who are skilled and have more abilities put in more effort than less-skilled employees. For employee retention, this theory can be used to predict the level of employee satisfaction. Employee satisfaction can be achieved through an employee's perception of equity in the organization [62-64]. They are more satisfied when they know that they are receiving fair rewards, because they expect fair and unbiased rewards.

\subsection{Social Exchange Theory}

George Homans proposed the social exchange theory. According to this theory, human behavior is directed by an exchange process, because their decisions are based on rational thinking. Employee commitment, employee motivation, and employee retention are predicted by social exchange. For example, if employees are working hard and putting their maximum effort into performing better but are not getting any reward in exchange for their efforts, these employees will no longer put in effort and their performance will go down $[65,66]$. This theory is usually used by researchers to explain the desired attitude and 
behavior of employees. From the perspective of this theory, organizational justice, organizational trust, and effective communication are important components for the retention of employees.

\subsection{Maslow's Theory}

According to Maslow, people want to become self-actualized, and they have different needs at different levels. This idea was proposed by Abraham Maslow in 1943. According to this theory, there are five levels, or stages, of needs (physiological, security, affiliation, esteem, and self-actualization) for humans (refer Table 2). Levels of motivation increase as needs are met. This theory is used in organizations to determine the level of needs of employees, and to motivate them through the provision of rewards. Furthermore, it offers useful insights for managers and organizations to retain their employees through a better reward system [67]. It is important to satisfy the unmet or emerging needs of employees through different programs. When managers design a reward system without knowing the unmet or emerging needs of employees, it results in poorer performance and lower employee satisfaction, and ultimately leads to an increase in the turnover rate. According to this theory, compensation, job security, safe working conditions, work relations, recognition, growth, and training and development are critical for retaining employees because these factors lead to employee satisfaction [68,69].

Table 2. Maslow's hierarchy of needs.

\begin{tabular}{cc}
\hline Needs & Application \\
\hline Physiological & Food \\
Security & Job security, appraisal, non-cash benefits (such as medical or health \\
insurance, life insurance), working conditions \\
Effiliation & $\begin{array}{c}\text { Employee engagement, collaborations, team spirit, social activities } \\
\text { Job rotation, Job enrichment, Career development, training } \\
\text { and development }\end{array}$ \\
Self-Actualization & Encouraging creativity, innovation and learning \\
\hline
\end{tabular}

\section{Interventions That Can Help to Improve Retention Strategies in the Hospitality Industry}

Based on the above-mentioned theories, a model (Figure 2) was developed. This model clearly shows that employee retention is dependent on employee satisfaction, and employee satisfaction depends on four factors including sustainable and positive work environment, sustainable and effective communication, sustainable growth opportunities, and sustainable and effective recruitment and selection practices [70-72]. These factors will not only lead to high satisfaction and, subsequently, a high retention rate but will also assist them in the development of economic and social sustainability growth. The notion of sustainability in HRM practices is important because it can intensify employment relationships and social participation, as well as helping employees to stimulate their positive attitude towards workplace retention. It has been found that there is a strong association between the identified factors and employee retention, as the organization's HR support, along with the social and economic contributions, facilitates employees' behavior to develop long-term retention commitment [73-76]. Hence, it has been deduced that the existence of such organizational factors and the promotion of sustainability growth through having good internal and external relationships will not only help the organization to reduce turnover but also attract new and talented employees [77].

\subsection{Sustainable and Positive Work Environment}

The work environment is a very critical factor for employee satisfaction. It has an impact on employees' perceptions of the organization. A conducive and environmentally protected work environment encourages and motivates employees to perform better, and this behavior is sustained throughout the day. Researchers believe that the working conditions, workplace culture, and work environment play important roles in deciding 
if employees will leave the organization or stay with it. The low employee retention rate in the hospitality industry is the result of low satisfaction levels and a poor quality of leadership [78]. The relevant literature suggests that employees' perceptions regarding the working environment in which they work is crucial and holds immense importance due to its impact on their intention to remain, customer retention, profitability, and customer loyalty [79,80]. Scott conducted a study in 2016 regarding employee retention in the hospitality industry. He found out that the operations of an organization in the hospitality industry are greatly affected or influenced by environmental factors, i.e., the person and environment fit together to create the appearance of a positive work environment. It is suggested that it's the manager's responsibility to create a conducive and sustainable work environment that motivates and inspires employees to perform better, accomplish their goals, and achieve organizational objectives. Employee dissatisfaction, low morale, poor performance, low productivity, and emotional exhaustion result from poor or negative work environments [28]. The work environment, flexible work hours, a humanistic workplace, a culture of recognition, and a diverse work environment influence employee decisions regarding quitting their jobs [29].

In the hospitality industry, employees usually do not have a balance between their work and private lives, and their workplace is not aligned with environmentally sustainable programs; this makes them more stressed at work as well as outside of work. These employees, with their poor work/life balance, also experience conflicts at work as well as in their private life. They experience more problems in their relationships, which lead to mental and physical health issues. Employees usually work night shifts as well. The industry puts burdens on their employees where they are expected to complete their work before leaving without considering the time. Most of the employees leave because they don't have opportunities to participate in the sustainable growth programs and/or have a clash between their personal life and professional life.

Work/life balance is affected by factors such as a lack of working hours, poor leave policies, an increased quantity of workload, and the unavailability of support structures within the workplace. When an organization or sector faces such challenges, they design policies that can help them handle the situation, but in the hospitality industry, strict policies have been implemented. The industry has designed and implemented very strict policies where employees do not have the authority to decide their working shift, benefits, or working hours, etc. Job rotation and job enrichment add variety to employees' daily responsibilities. Furthermore, employee empowerment helps employees to make decisions regarding their job responsibilities and working hours. However, in the hospitality industry, there is very little focus on these (mentioned) strategies. In the hospitality industry, the working hours are usually long. Employees have to work more than $9 \mathrm{~h}$ per day, which means that per week, the total number of working hours exceed $48 \mathrm{~h}$. Organizations need to show their employees that they are a valuable resource by creating a sustainable and positive working environment.

\subsection{Sustainible Growth Opportunities}

Sustainable growth opportunities refer to the sustainability of financial growth, career growth, and professional and personal growth opportunities for employees. Career growth or development can be defined as a formal perspective that is followed by companies/organizations to determine whether employees are available who are skilled and meet every aspect of the required job. It is the process of providing an ongoing mechanism that enhances the skills and knowledge of employees. Career development and growth opportunities are very critical for the success of the hospitality industry. The hospitality industry is growing very fast, but still, it has not adopted modern HR practices in its workplaces, and it is encountering challenges of environmental uncertainty. In 2016, most organizations in the hospitality industry introduced management trainee programs in which all of the employees (fresh graduates) completed their 6 months of training, but they always failed to promote them. For this reason, after 6 months of training, when employees 
are not promoted, they leave the organization. The industry invests a huge amount in its MTOs but fails to retain them. The main reason is that the industry not have structured career development programs or sustainable and environmental initiatives. The industry is not focusing on succession planning, talent management, and leadership development. The majority of the employees join this industry for a short period of time and use it as a stepping stone, not as a long-term career [30].

Employee career satisfaction can be achieved by providing a high level of career adaptability [31], which ultimately leads to a high retention rate [33,34]. According to Messmer, for employee retention, investing in training and career development programs is essential [81]. It is the responsibility of an organization to ensure that employees are growing and their skills are being developed [35]. Hospitality is a target-driven job, which is why the uncertainty and job insecurity level are very high at the entry level. Employees want to meet their desired level of productivity, for which they need support from the human resource department. Most organizations in the hospitality industry do not have sustainable management programs, and they don't have room to find the right direction for growth and development. This discourages the employee, and then they start looking for alternative options in other organizations and leave the company when they find another better opportunity. For this purpose, Figure 3 suggests that career development opportunities and self-directed and dynamic learning opportunities are essential for employee retention because they lead to employee satisfaction.

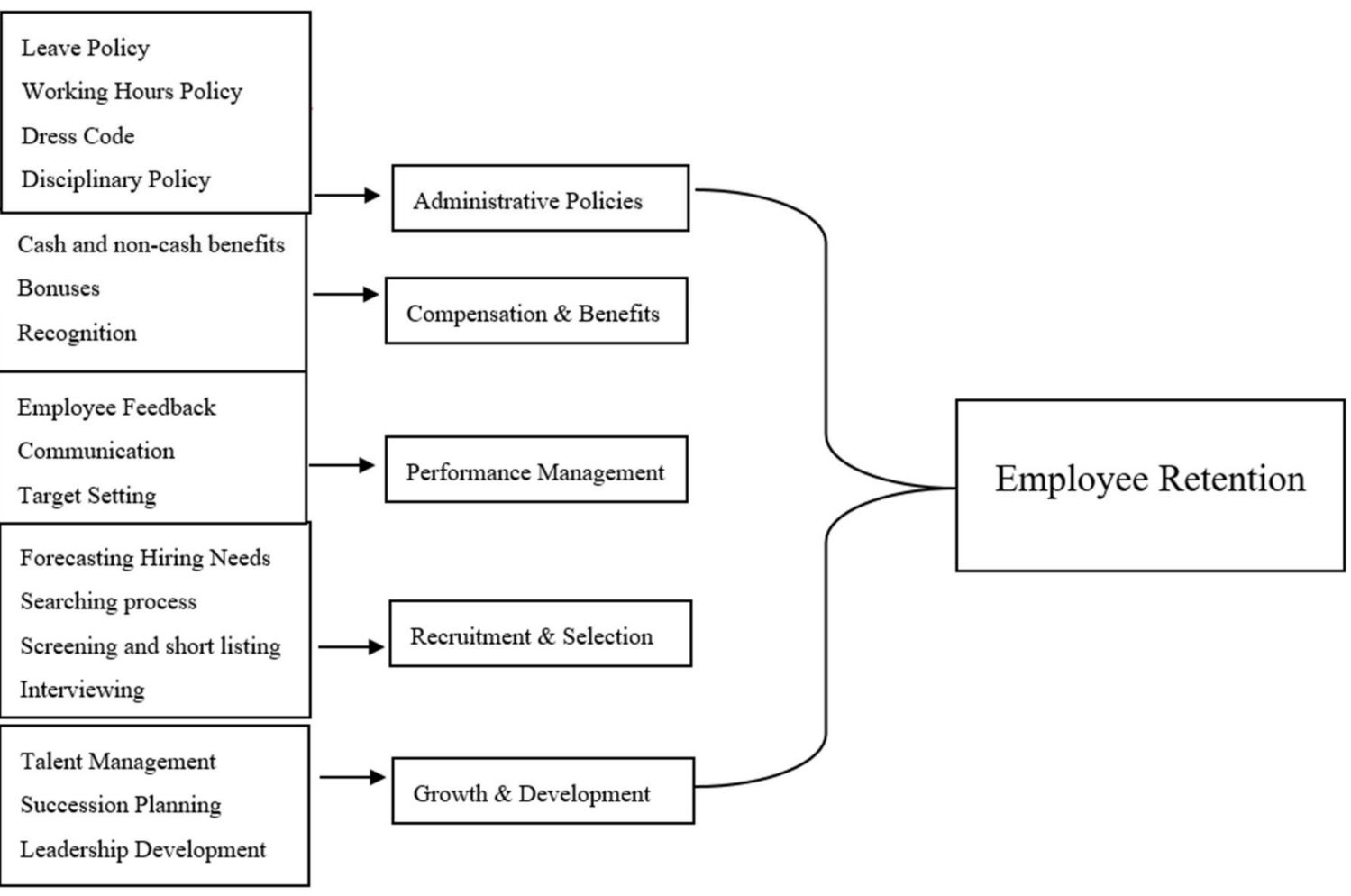

Figure 3. Impact of HR policies on employee retention.

\subsection{Sustainible and Effective Communication}

Sustainable and effective communication is a strategy that involves the integration of sustainable activities into the industry's operational and strategic objectives. A sustainable communication strategy assists organizations in developing and maintaining a healthy work culture by allowing them to effectively develop interpersonal, group, departmental, and intercultural communication. It also plays an important role in creating an open environment where employees have more opportunities to speak up in terms of suggestions regarding the organization's sustainable growth. The most effective way of communicating 
in the workplace is by creating a quality relationship between employees and their supervisors. When effective communication is implemented through the lowering of the power distance, providing regular feedback, conducting performance management meetings, conducting effective orientation programs, and encouraging teamwork, it helps employers to retain their employees. In the hospitality industry, if employees are allowed to participate in decision-making and they are provided with information regarding what is happening in the organization, they are more likely to stick with the organization because they consider themselves part of that company. Currently, this industry is struggling to engage employees. The power distance between managers and their subordinates is higher. Furthermore, due to poor communication, employees are not satisfied with their current salaries, rewards, or other benefits. The primary causes for this poor communication are that employees do not receive feedback, there is no idea of performance management meetings, no sustainability measures are implemented to ensure the organization's long-term survival, and there is no concept of mentorship. This is why employees lack confidence in their abilities [36]. In order to increase employee retention rates, managers must genuinely care about employees' social and environmental concerns, and must encourage effective communication in the workplace by providing timely feedback, conducting performance management meetings, encouraging transparency, and encouraging teamwork [37]. Researchers believe that employee engagement leads to employee retention because it encourages an employee to stick with the same organization for a longer period of time, and it gives a sense of satisfaction to employees [38]. Figure 3 shows the HR policies and their impacts on employee retention.

\subsection{Sustainable Recruitment and Selection Process}

The most significant reason behind the high turnover rate is the seasonal nature of the hospitality industry [39]. Usually, in the hospitality industry, managers recruit employees based on seasonal fluctuations. They remain ignorant of proper staffing plans and prerecruitment planning. Moreover, the hospitality industry greatly overlooks economic and social sustainability practices in the recruitment and selection process, which may cause employees' negative attitudes and them quitting the job.

Currently, the hospitality industry is focusing on hiring new fresh graduates with good academic backgrounds, and introducing their management trainee programs in universities to hire candidates with formal education, as many of their senior employees do not have a sound academic background. However, the industry is unable to retain them.

The recruitment and selection process of an organization determines the behavior and attitude of the hired employee, and whether or not the employee behavior and attitude are in accordance with the internal culture of the organization. Furthermore, it determines who might be the best fit for the organization. A properly designed recruitment process attracts competent candidates who are best matched with the job position and internal culture of the organization. When organizations use the best sustainability recruitment and selection practices, i.e., person-job fit and person-environment fit, it helps and enables them to choose the right person to fill a vacancy for a longer period. Skilled and best-fit employees introduce innovative ideas and unique methodologies for performing different processes; they increase the efficiency level of the task, which helps the organization to meet its organizational goals by increasing its productivity. Different researchers have identified positive relations or associations between the effective recruitment process and the retention rate of the organization. The use of formal selection and recruitment processes helps the organization to earn profits.

Sophisticated recruitment and selection procedures, as well as the critical role of sustainability practices, aid in the selection of the right person and increase the likelihood of retention for the organization. It has been found that the best recruitment practices and organizational performance are positively related. They help the company to achieve good results and improve the quality of its products and services. When the best employees are hired and then retained, it saves the cost of hiring the wrong people, who frequently leave the organization after some time. When the best people are identified, hired, trained, and 
retained, the financial burden is reduced. The role of sustainability in fostering and enabling an effective recruitment and selection process is crucial because, through sustainable practices, organizations can attain economic development and social participation that can help them greatly to attract and retain talented staff. A fast and efficient recruitment and selection process enhances the reputation of the company, makes it attractive to the best candidates, reduces the costs of the organization, and ensures that the very best talent is identified, engaged, and brought into the business.

\section{Proposed Model of Recruitment and Selection}

The proposed model (Figure $4 \mathrm{a}-\mathrm{c}$ ) of the recruitment and selection of employees in the hospitality industry can be divided into three phases: (1) staffing planning (prerecruitment), (2) implementation, and (3) onboarding (post-recruitment).

\subsection{Staffing Planning (Pre-Recruitment)}

A staffing plan is the first step to effective recruitment and selection (Figure 4a). Through a staffing plan, the human resource department identifies the personnel needs of the organization, such as the number of positions required to be filled, the number of employees to be trained, and the number of employees to be promoted in order to achieve organizational goals. Figure 4 shows the pre-recruitment scenario, in which the staffing plan is the first step, which is followed by job analysis, recruitment and on-boarding. In order to hire the best candidate for any organization, it is necessary to prepare the best job description that explains the job responsibilities, specifications, roles, and other important aspects of the job position. This helps the candidate to determine if the role is suitable to align with their skills and career goals, and makes the organization attractive to candidates. In order to design the job description, the recruiters must first understand the specific job position (by understanding the job role, position, specification, responsibilities, and importance of the position). Furthermore, he/she should understand the importance of the role to the achievement of the goals of the organization. Recruiters can understand it by discussing it with the senior head or lead of the division where the recruitment is needed. A clear, detailed, and effective job description can be created based on discussion. The staffing plan does not end with recruitment and selection; it also includes onboarding, succession planning, employee satisfaction, and employee retention.

\subsection{Implementation (Recruitment Process/Recruitment Strategy)}

The second phase is the recruitment and selection strategy. The problem with the industry's recruitment system is that they are still following traditional methods of hiring employees (see Figure 4b), in which recruiters think that their role ends when they hire employees. After recruiting, when employees join the organization, the task of the recruiter does not end. They should plan how to retain those employees. They should provide opportunities for them to learn and grow in their field. This can be done through continuous and ongoing performance management.

For effective recruitment, they should identify advanced sources of recruitment and communication methods. Understanding each step and implementing the correct procedure is necessary in order to find the right applicant. The manager should be aware of the type of experience required for the specific job. The following are some of the suggested ways of hiring the best fit. The model for recruitment and selection in Figure 4 suggests several steps for recruiting employees. It includes assessments, reference checks, physical exams, personality tests, and ongoing performance management that helps the employer to evaluate an employee's job success. Employers can also use the option of internal hiring as this imperative can strengthen the process of succession planning and subsequently motivate the employees to keep staying. Another option is visiting different educational placement offices. This will help the company to find fresh graduates and skilled students who are sharp, intelligent, and ready to join the organization. When a company hires this type of student and retains them in the company, it can benefit them in several ways. The 
first thing is that their cost (salary cost) is lower compared to other candidates. It is easy to fit them into the company culture. They also want to grow, for which they work hard. In addition, the most important and frequent using platform is social media i.e., Facebook, Twitter, and especially LinkedIn etc., where companies search for candidates to promote themselves to.
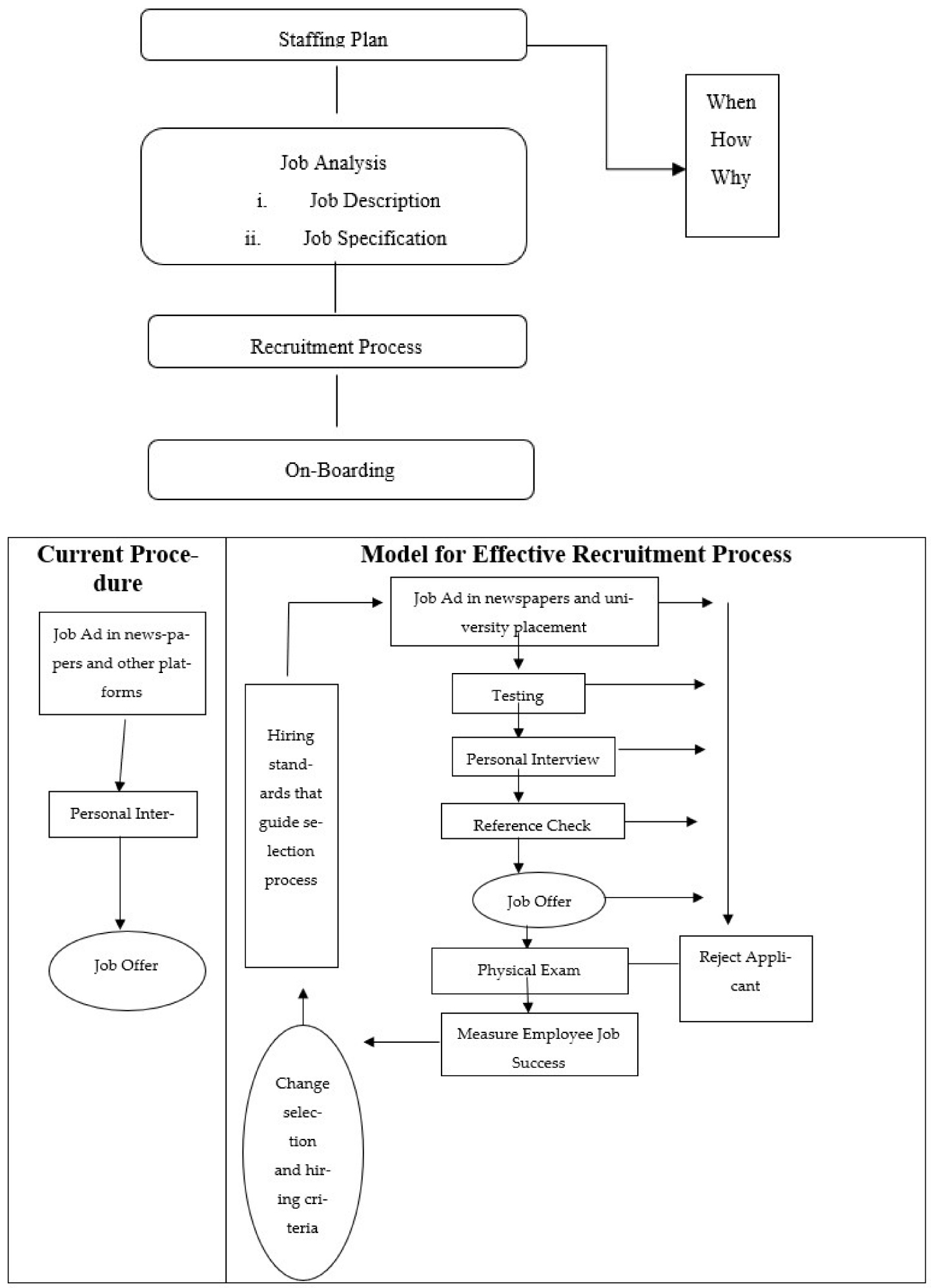

(b)

Figure 4. Cont. 


\section{Effective on Boarding System}

\author{
Preparation/Compliance \\ - Orientation/Culture \\ - Integration \\ - Engagement/Connection \\ - Follow-up/Clarification
}

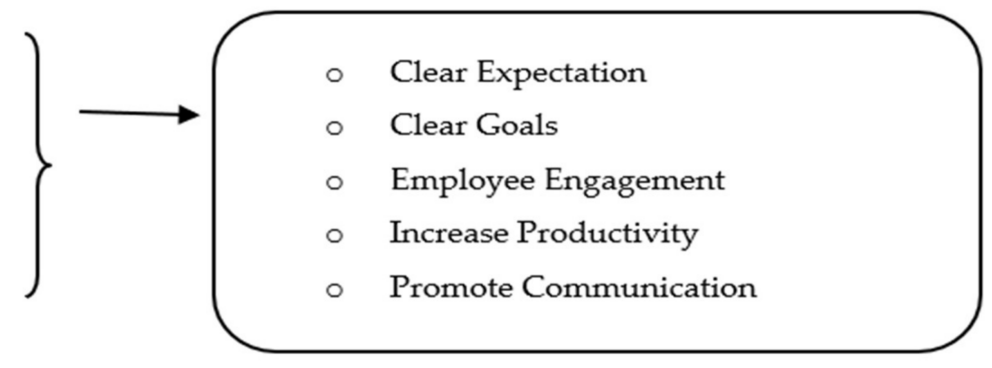

Figure 4. (a) Phases (1), staffing planning (pre-recruitment); (b) phase (2), implementation; (c) phase (3), onboarding (post-recruitment).

\subsection{Internal Hiring (Strengthening Succession Planning)}

This is the most important task for any organization. They should strengthen their succession planning so that when any member leaves the job, they will be able to assign that position to another person who has been trained and guided to do that task. This will help them to provide better services to their customer accounts. They will not face issues when employees leave the job.

The company needs to consider this option and frequently visit different educational institutes' placement offices. This will help the company to find fresh graduates and skilled students who are sharp, intelligent, and ready to join the organization. When a company hires this type of student and retains them in the company, it can benefit them in several ways. The first thing is that their cost (salary cost) is lower compared to other candidates. It is easy to fit them into the company culture. They also want to grow, for which they work hard.

In today's world, the most important platforms for job ads are social media: websites, Facebook, etc., and especially LinkedIn, where companies search for candidates to promote themselves to. For this industry, it will be very helpful to maintain a social media presence.

\subsection{Onboarding (Post-Recruitment)}

On-boarding is overlooked by most of the organizations in this industry, but it is the most important factor that affects employee retention in an organization. With the help of onboarding, organizations can explain the work and social environment of the organization, which will help the candidates to align their behavior with the internal culture of the organization before joining. Furthermore, the organization should identify things that make them more interesting and attractive for candidates to share with employees during the onboarding session. Likewise, mentioning perks and benefits (including noncash compensation as well) makes the organization interesting because it makes a big difference. Candidates (especially fresh graduates) always look for a role that allows them to learn and develop. This is why explaining the role is necessary. For example, mentioning how a particular role will help the candidate to learn and develop is a good idea. For effective onboarding, the organization should decide what impression they want to make on newly hired employees before implementing the onboarding session. For example, they should decide the role of each department, the goals that are to be communicated with newly hired employees, the expectations of the organization from them, and most importantly, the culture and working environment of the organization. Another important factor that affects employee retention in an organization that should be discussed in the onboarding program is career opportunities. Newly hired employees should be encouraged to communicate their expectations of the job and the organization regarding their career growth and learning and training programs.

This will help the employer to set clear expectations and goals for the newly hired employees. Likewise, it will help the newly hired employees to know the expectations of the employer and set their goals accordingly. Effective onboarding will help this industry 
retain its employees. An effective onboarding process results in clear expectations, clear goals, employee engagement, increased productivity, promoted communication, job satisfaction, and commitment to the organizational goal. At the end of the first year, traditional onboarding transitions into retention and employee satisfaction.

\section{Discussion}

The purpose of this review study was to identify and recommend strategies that can reduce employee turnover rates in the hospitality industry. The study proposed a model through which employee retention issues can be effectively addressed. This model helps practitioners and academicians to understand the strategies for retaining employees. Based on the study findings, it is suggested that the hospitality industry should pay more attention to their recruitment and selection practices. It was observed that, due to traditional HR practices, the industry was following a traditional way of hiring employees. The hospitality industry is currently using a traditional method of hiring, but the most advanced methods of recruitment (Figure $4 \mathrm{a}-\mathrm{c}$ ) were suggested, which are used by most other industries. This includes some additional steps that will help the company find the right person for the right job.

In this industry, most of the senior employees are satisfied with their respective organizations. The problem is that this industry needs qualified employees who have a sound academic background with new skills, such as a command of advanced technology (software) and new techniques to increase their productivity and the overall performance of the organization. All of the employees who have less or no qualifications and are working in this industry based on their extensive experience are loyal to the organization and do not want to leave, but most of the newly hired employees who join this industry leave after 6 months (approximately) and start looking for better opportunities. This shows that these organizations should consider compensation as the most important factor in the recruitment process, and for employee retention; on the other hand, salary is an important factor only at the beginning [82,83]. After some time, employees consider other factors as well, such as career development, the working environment, opportunities for growth, and learning and development. Moreover, they should revise their administrative policies to create a positive working environment in the organization. If an employee is required to work on weekends or a national holiday as a part of his/her normal work schedule to keep the business operations functional $24 \mathrm{~h}$ a day, then a shift arrangement should apply. For example, the organization should enable the employee to take annual leave to spend time with their family and to maintain a work/life balance, and should help the employee to take casual leave when required to attend to their obligations. They should also establish, maintain, implement, and communicate consistent, fair, transparent, and simple criteria for internal movement and promotion.

The internal work environment of this industry has become mediocre, as senior employees are happy but most of the newly hired employees leave the organization due to a lack of employee engagement, learning opportunities, training and coaching sessions, and management support for growth. Today's generation prefers coaching, learning, growing, and development over compensation. They need a job that can help them learn new skills, interact with other people, and receive continuous feedback on their performance. In order to retain employees, this industry needs to focus on growth opportunities; a positive work environment, effective communication skills, and most importantly, the implementation of effective recruitment and selection practices.

\subsection{Contributions/Significance of the Study}

The study has contributed in a twofold manner. First, it reviewed the literature to identify the causes and challenges of a rising rate of employee turnover in general, and particularly in the context of the hospitality industry. Second, the study proposed effective retention strategies that practitioners can use to keep their employees. In addition, the study 
provides a basis for future research to test the suggested model for employee retention in the hospitality industry.

\subsection{Limitations of the Study}

This research paper provides both practical and theoretical implications for the hospitality industry and other professionals. However, some limitations remain. The literature review provides a detailed overview of employee retention in the hospitality industry. However, only those research papers that were published in English between 2010 and 2021 were considered. The second limitation of this study is that it is a literature review, in which the results are based on the interpretation of other researchers. Furthermore, the concept of employee retention is very broad. In every study, the researcher defined it from a different perspective. Some researchers defined it in the sense of the tendency to leave the current job, while others considered it to be leaving a current job for a better opportunity. Some studies considered involuntary turnover, while some considered voluntary turnover. A few studies even considered both, and generalized the results for both types of turnover. A large number of selected studies were based on internal factors affecting retention, while few studies considered external factors as well. This may lead to an incomplete analysis of employee retention in the hospitality industry.

\subsection{Future Research}

Due to limited time, only 163 studies were collected, but a literature review produces good results if it is based on a larger number of studies.

This study included research papers based on the international hospitality industry, however, future research can also be done on the comparison of local hospitality industry and international hospitality industry in order to highlight a gap and more insights that what other factors can affect employee retention rates in the hospitality industry.

\subsection{Managerial/Practical Implications}

The findings suggest that the hospitality industry can cope with the challenge of employee retention by employing the proposed model. The proposed model suggests that employee retention is dependent on employee satisfaction, which is comprised of four factors: a sustainable and positive work environment; sustainable growth opportunities; sustainable, effective communication; and sustainable and effective recruitment and selection practices. The integrated role of social and economic activities, along with all such factors, is also manifested due to their inclusive nature, ensuring the organization's sustainable growth and, consequently, employee retention. The top management of the hospitality industry, therefore, needs to pay close attention to it, and needs to expend effort to create a positive work environment that must be fair, unbiased, and socially and economically developed. A negative work environment reduces the level of employee engagement and employee satisfaction. Managers can start this process by identifying the root cause of the problem. Problems can be solved by establishing trust and transparency, prioritizing onboarding and training programs, offering flexible hours, and developing a strong work culture.

Another guideline regarding the retention of employees is offering career growth opportunities. Employees in the hospitality industry usually suffer from stress regarding their career growth. When employees are not provided with proper guidelines or mentorship regarding their career growth, a succession planning program, or proper lines of communication, this leads to a high turnover rate. Management needs to address this issue by identifying the root cause and associated behaviors of employees. In addition, management should focus on reducing the power distance in their respective organization, as well as the implementation of technology to facilitate effective communication among employees. Furthermore, it is necessary to have transparency in the workplace.

Effective recruitment and selection practices are the most important guidelines for employee retention in the hospitality industry. The results of this research study suggest 
some important managerial implications concerning the recruitment and selection of employees in the hospitality industry, which can be divided into three phases: (1) planning (pre-recruitment), (2) implementation, and (3) onboarding (post-recruitment). Effective hiring practices with a proper staffing plan and an on-boarding system will help organizations to retain their employees. They should use different assessment methods, personality testing, and different software to know every aspect of employee behaviors and attitudes. This will help the organizations to know the short- and long-term goals of the candidates, their plans, and the competence of the employees, and it will also help them to ensure the long-term retention of an employee.

\section{Conclusions}

This research paper synthesized the results and findings of 48 papers. It was concluded that developing and implementing different retention strategies would help the hospitality industry to be satisfied with their employees, and would consequently make the employees more committed to continuing to stay at their workplace. The findings of this study suggested that employees' levels of satisfaction, and subsequently their retention rate, are contingent on four factors: a sustainable, positive work environment; sustainable growth opportunities; sustainable, effective communication; and sustainable effective recruitment and selection practices. The suggested model is also beneficial in the era of COVID-19 due to its feasibility and applicability. At the time of COVID-19, the hospitality industry encountered various difficulties, especially for frontline workers interacting with customers, because they had to take care of customer safety and themselves as well [84]. Given that unexpected situation, keeping those employees at work is quite challenging; thus, organizations need effective strategies through which they can retain their employees. The study also found out that the reason for the low retention rate in the hospitality industry is complex, and is affected by several external as well as internal factors. This literature review indicated that satisfied employees are less likely to leave their current job, while unsatisfied employees are expected to leave their current job for better career opportunities. Different theories suggest different retention strategies. However, the hospitality industry must focus on revamping its recruitment and selection process.

Author Contributions: Conceptualization, B.G. and M.Z.; methodology, B.G.; validation, B.G. and K.R.M.; formal analysis, B.G.; investigation, B.G. and K.R.M.; resources, B.G., M.Z., K.R.M., R.U. and A.K.; data curation, B.G. and K.R.M.; writing-original draft preparation, B.G.; writing-review and editing, B.G.; visualization, B.G.; project administration, B.G., H.H., M.Z. and R.U.; funding acquisition, M.Z., H.H., A.A.-M. and L.A.-C. All authors have read and agreed to the published version of the manuscript.

Funding: This research received no external funding.

Institutional Review Board Statement: Because of the observational nature of the study, and in the absence of any involvement of therapeutic medication, no formal approval of the Institutional Review Board of the local Ethics Committee was required. Nonetheless, all subjects were informed about the study and participation was fully on a voluntary basis. Participants were ensured of confidentiality and anonymity of the information associated with the surveys. The study was conducted according to the guidelines of the Declaration of Helsinki.

Informed Consent Statement: Informed consent was obtained from all subjects involved in the study.

Data Availability Statement: The dataset used in this research is available upon request from the corresponding author. The data are not publicly available due to restrictions, i.e., privacy or ethical restrictions.

Conflicts of Interest: The authors declare no conflict of interest. 


\section{Appendix A}

Table A1. Reasons for personnel movement.

\begin{tabular}{|c|c|c|}
\hline Reasons/Root Causes & Author's/Studies & Findings/Occurrence \\
\hline $\begin{array}{c}\text { Toxic Workplace Culture } \\
\text { and Values }\end{array}$ & [20-23] & $\begin{array}{l}\text { Toxic workplace cultures badly influence employees' perception leading their } \\
\text { high turnover rate. } \\
\text { Non-toxic culture and ethical values helps retaining employees. }\end{array}$ \\
\hline $\begin{array}{l}\text { Not having proper policies } \\
\text { of Monetary rewards }\end{array}$ & [24-26] & $\begin{array}{c}\text { When employees' best performance not get rewarded by the incentives, } \\
\text { bonuses, and other monetary rewards, they become demotivated and quit } \\
\text { their workplace. } \\
\text { There should be competitive reward and compensation policies to retain } \\
\text { the employees. }\end{array}$ \\
\hline $\begin{array}{c}\text { Rigid Organizational } \\
\text { Policies }\end{array}$ & [27-31] & $\begin{array}{l}\text { Rigid organizational policies influence employees' perception badly. } \\
\text { There must be flexible policies as it helps employees to get connect with the } \\
\text { organization for long. }\end{array}$ \\
\hline $\begin{array}{l}\text { Less opportunities for } \\
\text { learning and growth }\end{array}$ & [32-36] & $\begin{array}{l}\text { When employees don't have learning opportunities and career growth, their } \\
\text { level of energy might get down and they feel dissatisfied that lead them } \\
\text { switching somewhere better place. } \\
\text { Learning opportunities and career growth boost employees' motivation to } \\
\text { keep staying at their workplace. }\end{array}$ \\
\hline $\begin{array}{l}\text { No balance in employees } \\
\text { personal and } \\
\text { professional life }\end{array}$ & [37] & $\begin{array}{l}\text { When employees are having maximum conflicts between their personal and } \\
\text { professional life they would likely to leave the organization. } \\
\text { A good balance between work and life helps employees to enjoy their work } \\
\text { and get connected with the organization. }\end{array}$ \\
\hline $\begin{array}{l}\text { Less Quality relationship } \\
\text { between supervisor } \\
\text { and subordinate }\end{array}$ & [38-40] & $\begin{array}{l}\text { When employee's good performance doesn't get recognized and they don't get } \\
\text { respected by his/her supervisors, they feel bad and likely to leave } \\
\text { the workplace. } \\
\text { A quality relationship between supervisor and subordinate is important to } \\
\text { retain the employees. }\end{array}$ \\
\hline
\end{tabular}

Table A2. The role of human resource practices in the hospitality industry for employee retention.

\begin{tabular}{|c|c|}
\hline \multicolumn{2}{|r|}{ HR Practices } \\
\hline Administrative Polices & $\begin{array}{l}\text { Administrative policies are comparatively strict as compared to other industries which show that it } \\
\text { has role in low retention rate. Most of the employees prefer employee empowerment over other } \\
\text { benefits especially millennial. }\end{array}$ \\
\hline Compensation and Benefits & $\begin{array}{c}\text { Cash and non-cash both benefits of this sector are comparatively lesser than other industries. They } \\
\text { are not providing good salary packages that can attract best talent or retain existing employees. It is } \\
\text { evident that for retaining and attracting good employees it is necessary to offer } \\
\text { attractive compensation. }\end{array}$ \\
\hline Performance Management & $\begin{array}{l}\text { This industry has traditional performance management and do not have proper performance } \\
\text { management system. They conduct annual appraisals and promote employees on the basis of } \\
\text { appraisal ratings. Other industries have implemented modern HR practices where they follow } \\
\text { progressive approaches for engaging employees which help them to retain employees. }\end{array}$ \\
\hline Recruitment and Selection & $\begin{array}{l}\text { Their recruitment and selection system is also traditional where they are not considering modern } \\
\text { tools for hiring. Recently they have started focusing on hiring from university placement programs } \\
\text { but they are not successful in retaining these fresh graduates as their internal culture is not fulfilling } \\
\text { needs of these fresh graduates. There is no focus on post hiring promise. This shows that their } \\
\text { recruitment and selection process is not effective that is causing the high turnover rate in } \\
\text { this industry. }\end{array}$ \\
\hline Growth and Development & $\begin{array}{l}\text { Lack of growth and development is the most discussed cause of high turnover rate globally. In this } \\
\text { industry there is very less focus on career development of employees. Old traditional method is } \\
\text { used for communication and feedback where employees cannot share their long-term plans with } \\
\text { their respective bosses and cannot get their feedback/suggestions for their career development. }\end{array}$ \\
\hline
\end{tabular}


Table A3. Studies used for the content analysis.

\begin{tabular}{|c|c|c|}
\hline Author's Name and Year & Title & Publication Details \\
\hline $\begin{array}{l}\text { Aman-Ullah, A., Aziz, A., and } \\
\text { Ibrahim, H. (2020). }\end{array}$ & $\begin{array}{l}\text { A Systematic Review of Employee Retention: What's } \\
\text { Next in Pakistan? }\end{array}$ & $\begin{array}{l}\text { Journal of Contemporary Issues and } \\
\text { Thought, 10, 36-45. }\end{array}$ \\
\hline Dwesini, N. F. (2019). & $\begin{array}{l}\text { Causes and prevention of high employee turnover } \\
\text { within the hospitality industry: A literature review. }\end{array}$ & $\begin{array}{l}\text { African Journal of Hospitality, Tourism } \\
\text { and Leisure, 8(3), 1-15. }\end{array}$ \\
\hline Ampofo, J. A. (2020). & $\begin{array}{l}\text { Contributions of The Hospitality Industry (Hotels) } \\
\text { In the Development of Wa Municipality In Ghana. }\end{array}$ & $\begin{array}{l}\text { International Journal of Advanced } \\
\text { Economics, 2(2), 21-38. }\end{array}$ \\
\hline $\begin{array}{l}\text { Caselli, F., and Ciccone, A. } \\
\text { (2019). }\end{array}$ & $\begin{array}{l}\text { The human capital stock: A generalized } \\
\text { approach: comment. }\end{array}$ & $\begin{array}{l}\text { American Economic Review, 109(3), } \\
\text { 1155-1174. }\end{array}$ \\
\hline Pandita, D., and Ray, S. (2018). & $\begin{array}{l}\text { Talent management and employee engagement-a } \\
\text { meta-analysis of their impact on talent retention. }\end{array}$ & Industrial and Commercial Training. \\
\hline $\begin{array}{l}\text { Hales, Jeffrey, James R. Moon } \\
\text { Jr, and Laura A. Swenson. } \\
\text { (2018). }\end{array}$ & $\begin{array}{l}\text { "A new era of voluntary disclosure? Empirical } \\
\text { evidence on how employee postings on social media } \\
\text { relate to future corporate disclosures." }\end{array}$ & $\begin{array}{l}\text { Accounting, Organizations and Society } \\
\qquad 68 \text { (2018): 88-108. }\end{array}$ \\
\hline Griffin, Ricky W. (1991). & $\begin{array}{l}\text { "Effects of work redesign on employee perceptions, } \\
\text { attitudes, and behaviors: A long-term investigation." }\end{array}$ & $\begin{array}{l}\text { Academy of management Journal 34, no. } \\
\qquad 2 \text { (1991): 425-435. }\end{array}$ \\
\hline $\begin{array}{l}\text { Santhanam, N., T.J., K., } \\
\text { Dyaram, L. and Ziegler, H. } \\
\text { (2017). }\end{array}$ & $\begin{array}{l}\text { "Impact of human resource management practices } \\
\text { on employee turnover intentions: Moderating role of } \\
\text { psychological contract breach" }\end{array}$ & $\begin{array}{l}\text { Journal of Indian Business Research, Vol. } \\
9 \text { No. 3, pp. 212-228. https: } \\
\text { / / doi.org/10.1108/JIBR-10-2016-0116 } \\
\text { (accessed on } 12 \text { December 2021). }\end{array}$ \\
\hline $\begin{array}{l}\text { Nivethitha, Lata Dyaram, } \\
\text { T.J.Kamalanabhan, S. (2014). }\end{array}$ & $\begin{array}{l}\text { Human Resource Practices and Employee Turnover } \\
\text { Intentions in Hospitality Industry. }\end{array}$ & $\begin{array}{l}\text { Global Journal of Management and } \\
\text { Business Research, } \\
\text { https:/ /journalofbusiness.org/index. } \\
\text { php/GJMBR/article/view / } 1244 \\
\text { (accessed on } 12 \text { December 2021). }\end{array}$ \\
\hline $\begin{array}{l}\text { Curran, Sandra Revona. } \\
\qquad(2012)\end{array}$ & $\begin{array}{l}\text { "Assessing employee turnover in the Language } \\
\text { Services Section of Parliament of the Republic of } \\
\text { South Africa. }\end{array}$ & $\begin{array}{l}\text { PhD diss., Stellenbosch: Stellenbosch } \\
\text { University, } 2012 .\end{array}$ \\
\hline $\begin{array}{l}\text { Ezeuduji, Ikechukwu } \\
\text { Onyekwere, and Thandokazi } \\
\text { Lulu Mbane. (2017). }\end{array}$ & $\begin{array}{c}\text { "Length of service versus employee retention factors: } \\
\text { Hotels in Cape Town, South Africa." }\end{array}$ & $\begin{array}{l}\text { Acta Universitatis Danubius. Economica } \\
\qquad 13, \text { no. } 2 \text { (2017). }\end{array}$ \\
\hline $\begin{array}{l}\text { Crawford, Alleah and } \\
\text { Riscinto-Kozub, Kristen } \\
\text { (2011). }\end{array}$ & $\begin{array}{c}\text { "The Role of the Employee: An Exploratory Study in } \\
\text { Service Recovery Satisfaction in the Luxury } \\
\text { Resort Industry," }\end{array}$ & $\begin{array}{l}\text { Journal of Tourism Insights: Vol. 1: Iss. 1, } \\
\text { Article 4. Available at: } \\
\text { https:/ / doi.org/10.9707/2328-0824.1003 } \\
\text { (accessed on } 12 \text { December 2021). }\end{array}$ \\
\hline $\begin{array}{l}\text { Lee, Chang, and Kelly Way. } \\
\text { (2010). }\end{array}$ & $\begin{array}{c}\text { "Individual employment characteristics of hotel } \\
\text { employees that play a role in employee satisfaction } \\
\text { and work retention." }\end{array}$ & $\begin{array}{l}\text { “International Journal of Hospitality } \\
\text { Management 29, no. } 3 \text { (2010): 344-353. }\end{array}$ \\
\hline $\begin{array}{l}\text { Mita, M., Aarti K. and } \\
\text { Ravneeta, D. (2014). }\end{array}$ & Study on Employee Retention and Commitment. & $\begin{array}{l}\text { International Journal of Advance } \\
\text { Research in Computer Science and } \\
\text { Management Studies, 2, 154-164. }\end{array}$ \\
\hline $\begin{array}{l}\text { Bidisha, L. D and Mukulesh, B. } \\
\text { (2013). }\end{array}$ & Employee Retention: A Review of Literature. & $\begin{array}{l}\text { Journal of Business and Management, 14, } \\
\text { 8-16. }\end{array}$ \\
\hline $\begin{array}{l}\text { Rehman, N. and Mubashar, T. } \\
\text { (2017). }\end{array}$ & $\begin{array}{l}\text { Job stress, Psychological Capital and Turnover } \\
\text { Intentions in Employees of Hospitality Industry. }\end{array}$ & $\begin{array}{l}\text { Journal of Behavioral Sciences, 27(2), } \\
\text { 59-79. }\end{array}$ \\
\hline $\begin{array}{l}\text { Kuria, S., Ondigi, A. and } \\
\text { Wanderi, P. M. (2012). }\end{array}$ & $\begin{array}{l}\text { Assessment of causes of labor turnover in three and } \\
\text { five star-rated hotels in Kenya. }\end{array}$ & $\begin{array}{l}\text { International Journal of Business and } \\
\text { Social Sciences, 3(15), 311-317. }\end{array}$ \\
\hline Ming-Chu, Y. (2017). & $\begin{array}{l}\text { How Can Human Resource Management Practices } \\
\text { Lead to Increased Corporate Social Performance? } \\
\text { Institutional Theory Perspective. }\end{array}$ & $\begin{array}{c}\text { Management Challenges in a Network } \\
\text { Economy, 17-19. }\end{array}$ \\
\hline
\end{tabular}


Table A3. Cont.

\begin{tabular}{cr}
\hline Author's Name and Year & Title \\
\hline $\begin{array}{c}\text { Rehman, N., and Hassan, A. } \\
\text { (2019). }\end{array}$ & $\begin{array}{c}\text { Transforming into a learning organization through } \\
\text { HR initiatives and managerial factors: A case of } \\
\text { avari hotel, Lahore. }\end{array}$
\end{tabular}

Rok, M. and Mulej, M. (2014).

CSR-based model for HRM in tourism and hospitality.

Davidson, M. C. G., Timo, N., and Wang, Y. (2010).

How much does labor turnover cost? A case study of Australian four-five star hotels.

\author{
Publication Details \\ Journal of Management and Research, \\ 3(1), 1-24. https: \\ / / doi.org/10.29145/jmr/31/0301001 \\ (accessed on 12 December 2021).
}

Kybernetes, 43(3/4), 346-362.

A case study of Australian four-five star hotels. International Journal of

Contemporary Hospitality Management, 22(4), Pp.451-466.

Doi:10.1108/09596111011042686q

Faldetta, G., Fasone, V., and Turnover in the hospitality industry: Can reciprocity Provenzano, C. (2013). solve the problem?

Pasos: Revista de Turismo y Patrimonio Cultural, 11, 583-595. Retrieved from http:/ / www.pasosonline.org (accessed on 12 December 2021).

Shukla, A., Srinivasan, R. and Chaurasia, S. (2013).

Chan, S. H., and Kuok, O. M. (2011).

A study of human resources recruitment, selection, and retention issues in the hospitality and tourism industry in Macau.
Indian Journal of Industrial Relations, 49(1), 111-122

Journal of Human Resources in Hospitality and Tourism, 10(4), 421-441. https:/ / doi.org/10.1080/15332845.2011. 588579 (accessed on 12 December 2021).

African Journal of Hospitality, Tourism and Leisure, Volume 8 (3) - (2019). https: //www.ajhtl.com/uploads/7/1/6/3/71 63688/article_38_vol_8_3_2019.pdf

(accessed on 12 December 2021).

Chan, S. H. J. and Mai, X. The relation of career adaptability to satisfaction and (2015). turnover intentions. 130-139.

The Antecedent of Customer Satisfaction and Its Impact on Customer Retention in Tourism as Hospitality Industry.

Barusman, A. R. P., Rulian, E.
P., and Susanto, S. (2019).

A study on use of E- Resources in recruitment and selection process in 5 star hotels.

Sherkar, A. (2015).

ATITHYA: A Journal of Hospitality, 1(1). https:/ / doi.org/10.21863/atithya/2015 .1.1.002 (accessed on 12 December 2021).

\section{Eversole, B., Venneberg, D. and Crowder, C. (2012).}

Tews, Michael J., John W. Michel, and Kathryn Stafford. (2020).

Zopiatis, A. and Theocharous, C.P. (2014).

Creating a flexible organizational culture to attract and retain talented workers across generations.

“Social support and turnover among entry-level service employees: Differentiating type, source, and basis of attachment."
Job involvement, satisfaction and turnover: Evidence from hotel employees in Cyprus.

Hotel recruitment and selection practices: The case of the Greek hotel industry.
Advances in Developing Human Resources, 14 (4), 607-625.

“Human Resource Management 59, no. 3 (2020): 221-234.
Chytiri, A., Filippaios, F., and Chytiris, L. (2018).

\section{Chan, Sow Hup Joanne, and Xin Mai. (2015).}

Raub, S. and Robert, C. (2013).
"The relation of career adaptability to satisfaction and turnover intentions."

Empowerment, organizational commitment, and voice behavior in the hospitality industry evidence from a multinational sample.
Tourism Management, 41, 129-140.

International Journal of Organizational

Leadership, 7(3), 324-339. https:

/ / doi.org/10.33844/ijol.2018.60465 (accessed on 12 December 2021).

“Journal of Vocational Behavior 89 (2015): 130-139.

Cornell Hospitality Quarterly, 54(2), 136-148.

International Journal of Hospitality Management, 35, 48-58. 
Table A3. Cont.

\begin{tabular}{|c|c|c|}
\hline Author's Name and Year & Title & Publication Details \\
\hline $\begin{array}{c}\text { Marinakou, E., and } \\
\text { Giousmpasoglou, C. (2019). }\end{array}$ & $\begin{array}{l}\text { Talent management and retention strategies in } \\
\text { luxury hotels: Evidence from four countries. }\end{array}$ & $\begin{array}{l}\text { International Journal of Contemporary } \\
\text { Hospitality Management. }\end{array}$ \\
\hline $\begin{array}{l}\text { Irabor, I. E., and Okolie, U. C. } \\
\text { (2019). }\end{array}$ & $\begin{array}{l}\text { A review of employees' job satisfaction and its effect } \\
\text { on their retention. Annals of Spiru Haret University. }\end{array}$ & Economic Series, 19(2), 93-114. \\
\hline $\begin{array}{l}\text { Davidson, M. C. G., Timo, N., } \\
\text { and Wang, Y. (2010). }\end{array}$ & $\begin{array}{l}\text { How much does labor turnover cost? A case study } \\
\text { of Australian four-five star hotels. }\end{array}$ & $\begin{array}{c}\text { International Journal of Contemporary } \\
\text { Hospitality Management, 22(4), } \\
\text { Pp.451-466. } \\
\text { Doi:10.1108/09596111011042686q }\end{array}$ \\
\hline $\begin{array}{l}\text { Faldetta, G., Fasone, V., and } \\
\text { Provenzano, C. (2013). }\end{array}$ & $\begin{array}{l}\text { Turnover in the hospitality industry: Can reciprocity } \\
\text { solve the problem? }\end{array}$ & $\begin{array}{l}\text { Pasos: Revista de Turismo y Patrimonio } \\
\text { Cultural, 11, 583-595. Retrieved from } \\
\text { http:/ / www.pasosonline.org (accessed } \\
\text { on } 12 \text { December 2021). }\end{array}$ \\
\hline $\begin{array}{l}\text { Shukla, A., Srinivasan, R. and } \\
\text { Chaurasia, S. (2013). }\end{array}$ & $\begin{array}{l}\text { Impact of work related attitudes on } \\
\text { turnover intentions. }\end{array}$ & $\begin{array}{l}\text { Indian Journal of Industrial Relations, } \\
49(1), 111-122 .\end{array}$ \\
\hline $\begin{array}{l}\text { Nombeko Felicity Dwesini. } \\
\text { (2019). }\end{array}$ & $\begin{array}{l}\text { Causes and prevention of high employee turnover } \\
\text { within the hospitality industry: A literature review. }\end{array}$ & $\begin{array}{c}\text { African Journal of Hospitality, Tourism } \\
\text { and Leisure, Volume } 8 \text { (3). } \\
\text { https: } \\
\text { / / www.ajhtl.com/uploads/7/1/6/3/71 } \\
\text { 63688/article_38_vol_8_3_2019.pdf } \\
\text { (accessed on 12 December 2021). }\end{array}$ \\
\hline Sherkar, A. (2015). & $\begin{array}{l}\text { A study on use of E- Resources in recruitment and } \\
\text { selection process in } 5 \text { star hotels. }\end{array}$ & $\begin{array}{l}\text { ATITHYA: A Journal of Hospitality, 1(1). } \\
\text { https:/ / doi.org/10.21863/atithya/2015 } \\
\text {.1.1.002 (accessed on } 12 \text { December 2021) }\end{array}$ \\
\hline Dwesini, N. F. (2019). & $\begin{array}{l}\text { Causes and prevention of high employee turnover } \\
\text { within the hospitality industry: A literature review. }\end{array}$ & $\begin{array}{l}\text { African Journal of Hospitality, Tourism } \\
\text { and Leisure, 8(3), 1-15. }\end{array}$ \\
\hline $\begin{array}{l}\text { Chytiri, A., Filippaios, F., and } \\
\text { Chytiris, L. (2018). }\end{array}$ & $\begin{array}{l}\text { Hotel recruitment and selection practices: The case } \\
\text { of the Greek hotel industry. }\end{array}$ & $\begin{array}{c}\text { International Journal of Organizational } \\
\text { Leadership, 7(3), 324-339. } \\
\text { https: } \\
\text { / / doi.org/10.33844/ijol.2018.60465 } \\
\text { (accessed on } 12 \text { December 2021) }\end{array}$ \\
\hline $\begin{array}{l}\text { Marinakou, E., and } \\
\text { Giousmpasoglou, C. (2019). }\end{array}$ & $\begin{array}{l}\text { Talent management and retention strategies in } \\
\text { luxury hotels: Evidence from four countries. }\end{array}$ & $\begin{array}{c}\text { International Journal of Contemporary } \\
\text { Hospitality Management. }\end{array}$ \\
\hline $\begin{array}{l}\text { Mohsin, A., Lengler, J. and } \\
\text { Kumar, B. (2013). }\end{array}$ & $\begin{array}{l}\text { Exploring the antecedents of intentions to leave the } \\
\text { job: the case of luxury hotel staff. }\end{array}$ & $\begin{array}{l}\text { International Journal of Hospitality } \\
\text { Management, 35, 48-58. }\end{array}$ \\
\hline $\begin{array}{l}\text { Pitts, D., Marvel, J., and } \\
\text { Fernandez, S. (2011). }\end{array}$ & $\begin{array}{l}\text { So hard to say goodbye? Turnover intention among } \\
\text { US federal employees. }\end{array}$ & $\begin{array}{l}\text { Public Administration Review, 71(5), } \\
\text { 751-760. }\end{array}$ \\
\hline
\end{tabular}

\section{References}

1. Aman-Ullah, A.; Aziz, A.; Ibrahim, H. A Systematic Review of Employee Retention: What's next in Pakistan? J. Contemp. Issues Thought 2020, 10, 36-45. [CrossRef]

2. Dwesini, N.F. Causes and prevention of high employee turnover within the hospitality industry: A literature review. Afr. J. Hosp. Tour. Leis. 2019, 8, 1-15.

3. Ohunakin, F.; Adeniji, A.A.; Ogunlusi, G.; Igbandumhe, F.; Sodeinde, A.G. Talent retention strategies and employees' behavioural outcomes: Empirical evidence from hospitality industry. Bus. Theory Pract. 2020, 21, 192-199. [CrossRef]

4. Wagner, M. Environmental management activities and sustainable HRM in German manufacturing firms-incidence, determinants, and outcomes. Ger. J. Hum. Resour. Manag. 2011, 25, 157-177. [CrossRef]

5. Ampofo, J.A. Contribution of the Hospitality Industry (Hotels) in the development of WA Municipality in Ghana. Int. J. Adv. Econ. 2020, 2, 21-38. [CrossRef]

6. Nivethitha, S.; Dyaram, L.; Kamalanabhan, T.J. Human Resource Practices and Employee Turnover Intentions in Hospitality Industry. Glob. J. Manag. Bus. Res. 2014. Available online: https://journalofbusiness.org/index.php/GJMBR/article/view/1244 (accessed on 12 December 2021). 
7. Curran, S.R. Assessing Employee Turnover in the Language Services Section of Parliament of the Republic of South Africa. Ph.D. Thesis, Stellenbosch University, Stellenbosch, South Africa, 2012.

8. Ezeuduji, I.O.; Mbane, T.L. Length of service versus Employee retention factors: Hotels in Cape Town, South Africa. Acta Univ. Danubius. OEconomica 2017, 13. Available online: http://journals.univdanubius.ro/index.php/oeconomica/article/view/3743 (accessed on 12 December 2021).

9. Lin, J.T.P.; Ping, N.C.L. Perceived job autonomy and employee engagement as predictors of organizational commitment. Undergrad. J. Psychol. 2016, 29, 1-16.

10. Crawford, A.; Riscinto-Kozub, K. The Role of the Employee: An Exploratory Study in Service Recovery Satisfaction in the Luxury Resort Industry. J. Tour. Insights 2011, 1, 4. [CrossRef]

11. Faldetta, G.; Fasone, V.; Provenzano, C. Turnover in the hospitality industry: Can reciprocity solve the problem? PASOS Rev. Tur. Patrim. Cult. 2013, 11, 583-595. [CrossRef]

12. Caselli, F.; Ciccone, A. The human capital stock: A generalized approach: Comment. Am. Econ. Rev. 2019, 109, 1155-1174. [CrossRef]

13. Park, J.; Min, H.K. Turnover intention in the hospitality industry: A meta-analysis. Int. J. Hosp. Manag. 2020, 90, 102599. [CrossRef]

14. Goh, E.; Okumus, F. Avoiding the hospitality workforce bubble: Strategies to attract and retain generation $\mathrm{Z}$ talent in the hospitality workforce. Tour. Manag. Perspect. 2020, 33, 100603. [CrossRef]

15. Gebbels, M. What makes a hospitality professional? Hosp. Insights 2019, 3, 5-6. [CrossRef]

16. Hales, J.; James, R.M., Jr.; Laura, A. Swenson. A new era of voluntary disclosure? Empirical evidence on how employee postings on social media relate to future corporate disclosures. Account. Organ. Soc. 2018, 68, 88-108. [CrossRef]

17. Sheridan, J.E. Organizational culture retention. Acad. Manag. J. 1992, 35, 1036-1056.

18. Horwitz, F. Human resources management in multinational companies in Africa: A systematic literature review. Int. J. Hum. Resour. Manag. 2015, 26, 2786-2809. [CrossRef]

19. Alkitbi, S.S.; Alshurideh, M.; Al Kurdi, B.; Salloum, S.A. Factors affect customer retention: A systematic review. In International Conference on Advanced Intelligent Systems and Informatics; Springer: Cham, Switzerland, 2020; pp. 656-667.

20. Nieves, J.; Quintana, A. Human resource practices and innovation in the hotel industry: The mediating role of human capital. Tour. Hosp. Res. 2018, 18, 72-83. [CrossRef]

21. Lee, C.; Way, K. Individual employment characteristics of hotel employees that play a role in employee satisfaction and work retention. Int. J. Hosp. Manag. 2010, 29, 344-353. [CrossRef]

22. Krasman, M. Three Must-Have Onboarding Elements for New and Relocated Employees. Employ. Relat. Today 2015, 42, 9-14. [CrossRef]

23. Santhanam, N.; Kamalanabhan, T.J.; Dyaram, L.; Ziegler, H. Impact of human resource management practices on employee turnover intentions: Moderating role of psychological contract breach. J. Indian Bus. Res. 2018, 9, 212-228. [CrossRef]

24. Ziegler, R.T. The Impact of Strategic Planning Involvement on Employee Engagement in a Federal Public Health Agency. Ph.D. Thesis, Pepperdine University, Malibu, CA, USA, 2017.

25. Mita, M.; Aarti, K.; Ravneeta, D. Study on Employee Retention and Commitment. Int. J. Adv. Res. Comput. Sci. Manag. Stud. 2014, $2,154-164$.

26. Bichler, B.F.; Petry, T.; Peters, M. We did everything we could': How employees' made sense of COVID-19 in the tourism and hospitality industry. Curr. Issues Tour. 2021, 1-17. [CrossRef]

27. Dehghan Nayeri, N.; Salehi, T.; Ali Asadi Noghabi, A. Quality of work life and productivity among Iranian nurses. Contemp. Nurse 2011, 39, 106-118. [CrossRef]

28. Bidisha, L.D.; Mukulesh, B. Employee Retention: A Review of Literature. J. Bus. Manag. 2013, 14, 8-16.

29. Rehman, N.; Mubashar, T. Job stress, Psychological Capital and Turnover Intentions in Employees of Hospitality Industry. J. Behav. Sci. 2017, 27, 59-79.

30. Mohsin, A.; Lengler, J.; Kumar, B. Exploring the antecedents of intentions to leave the job: The case of luxury hotel staff. Int. J. Hosp. Manag. 2013, 35, 48-58. [CrossRef]

31. Pitts, D.; Marvel, J.; Fernandez, S. So hard to say goodbye? Turnover intention among US federal employees. Public Adm. Rev. 2011, 71, 751-760. [CrossRef]

32. Korczynski, M. Human Resource Management in the Service Sector; Palgrave: Basingstoke, UK, 2002.

33. Dockel, A.; Basson, J.S.; Coetzee, M. The effect of retention factors on organisational commitment: An investigation of high technology employees. SA J. Hum. Resour. Manag. 2006, 4, 20-28. [CrossRef]

34. Kuria, S.; Ondigi, A.; Wanderi, P.M. Assessment of causes of labor turnover in three and five star-Rated hotels in Kenya. Int. J. Bus. Soc. Sci. 2012, 3, 311-317.

35. Ihuah, P.W.; Kakulu, I.I.; Eaton, D. A review of Critical Project Management Success Factors (CPMSF) for sustainable social housing in Nigeria. Int. J. Sustain. Built Environ. 2014, 3, 62-71. [CrossRef]

36. Ming-Chu, Y. How Can Human Resource Management Practices Lead to Increased Corporate Social Performance? Institutional Theory Perspective. Manag. Chall. A Netw. Econ. 2017, 17-19. Available online: http://www.toknowpress.net/ISBN/978-961-69 14-21-5/papers/ML17-132.pdf (accessed on 12 December 2021). 
37. Rehman, N.; Hassan, A. Transforming into a learning organization through HR initiatives and managerial factors: A case of avari hotel, Lahore. J. Manag. Res. 2019, 3, 1-24. [CrossRef]

38. Irabor, I.E.; Okolie, U.C. A review of employees' job satisfaction and its effect on their retention. Annals of Spiru Haret University. Econ. Ser. 2019, 19, 93-114.

39. Rok, M.; Mulej, M. CSR-based model for HRM in tourism and hospitality. Kybernetes 2014, 43, 346-362. [CrossRef]

40. Armstrong, M. Human Resource Management Practice; Kogan Page Limited: London, UK, 2020.

41. Davidson, M.C.G.; Timo, N.; Wang, Y. How much does labor turnover cost? A case study of Australian four-five star hotels. Int. J. Contemp. Hosp. Manag. 2010, 22, 451-466. [CrossRef]

42. Shukla, A.; Srinivasan, R.; Chaurasia, S. Impact of work related attitudes on turnover intentions. Indian J. Ind. Relat. 2013, 49, 111-122.

43. Chan, S.H.; Kuok, O.M.; Eversole, B.; Venneberg, D.; Crowder, C. Creating a flexible organizational culture to attract and retain talented workers across generations. Adv. Dev. Hum. Resour. 2012, 14, 607-625.

44. A study of human resources recruitment, selection, and retention issues in the hospitality and tourism industry in Macau. J. Hum. Resour. Hosp. Tour. 2011, 10, 421-441. [CrossRef]

45. Spencer, D.G. Employee voice and employee retention. Acad. Manag. J. 1986, 29, 488-502.

46. Griffin, R.W. Effects of work redesign on employee perceptions, attitudes, and behaviors: A long-term investigation. Acad. Manag. J. 1991, 34, 425-435.

47. Bharwani, S.; Butt, N. Challenges for the global hospitality industry: An HR perspective. Worldwide Hospitality and Tourism Themes. 2012, 4, 150-162. [CrossRef]

48. Chan, S.H.J.; Mai, X. The relation of career adaptability to satisfaction and turnover intentions. J. Vocat. Behav. 2015, 89, 130-139. [CrossRef]

49. Barusman, A.R.P.; Rulian, E.P.; Susanto, S. The Antecedent of Customer Satisfaction and Its Impact on Customer Retention in Tourism as Hospitality Industry. Int. J. Adv. Sci. Technol. 2019, 28, 322-330.

50. Sherkar, A. A study on use of E- Resources in recruitment and selection process in 5 star hotels. ATITHYA A J. Hosp. 2015, 1, 14-19. [CrossRef]

51. Bauwens, R. Equity theory. In Canon van HRM; Tilburg University: Tilburg, The Netherlands, 2019 ; pp. $120-135$.

52. Solnet, D.; Kralj, A.; Kandampully, J. Generation Y employees: An examination of work attitude differences. J. Appl. Manag. Entrep. 2012, 17, 36

53. Das, S.C.; Singh, R.K. Green HRM and organizational sustainability: An empirical review. Kegees J. Soc. Sci. 2016, 8, 227-236.

54. Jabagi, N.; Croteau, A.-M.; Audebrand, L.K.; Marsan, J. Gig-workers' motivation: Thinking beyond carrots and sticks. J. Manag. Psychol. 2019, 34, 192-213. [CrossRef]

55. Tews, M.J.; John, W. Michel, and Kathryn Stafford. Social support and turnover among entry-level service employees: Differentiating type, source, and basis of attachment. Hum. Resour. Manag. 2020, 59, 221-234. [CrossRef]

56. Zopiatis, A.; Theocharous, C.P. Job involvement, satisfaction and turnover: Evidence from hotel employees in Cyprus. Tour. Manag. 2014, 41, 129-140. [CrossRef]

57. Baciu, L.E. Expectancy Theory Explaining Civil Servants'work Motivation. Evidence from a Romanian City Hall. USV Ann. Econ. Public Adm. 2018, 17, 146-160.

58. Porter, T.H.; Gerhardt, M.W.; Fields, D.; Bugenhagen, M. An exploratory study of gender and motivation to lead in millennials. J. Soc. Psychol. 2019, 159, 138-152. [CrossRef] [PubMed]

59. Guan, Y.; Guo, Y.; Bond, M.H.; Cai, Z.; Zhou, X.; Xu, J.; Zhu, F.; Wang, Z.; Fu, R.; Liu, S.; et al. New job market entrants' future work self, career adaptability and job search outcomes: Examining mediating and moderating models. J. Vocat. Behav. 2014, 85, 136-145. [CrossRef]

60. Zoller, Y.J.; Muldoon, J. Illuminating the principles of social exchange theory with Hawthorne studies. J. Manag. History 2018, 25, 47-66. [CrossRef]

61. Navy, S.L. Theory of human motivation-Abraham Maslow. In Science Education in Theory and Practice; Springer: Berlin/Heidelberg, Germany, 2020; pp. 17-28.

62. Jerome, N. Impact of sustainable human resource management and organizational performance. Int. J. Asian Soc. Sci. 2013, 3, 1287-1292.

63. Scott, S.B. Factors Influencing Teacher Burnout and Retention Strategies. Bachelor's Thesis, The University of Akron, Akron, OH, USA, 2019

64. Govaerts, N.; Kyndt, E.; Dochy, F.; Baert, H. Influence of learning and working climate on the retention of talented employees. J. Workplace Learn. 2011, 23, 35-55. [CrossRef]

65. Kar, S.; Misra, K.C. Nexus between work life balance practices and employee retention-The mediating effect of a supportive culture. Asian Soc. Sci. 2013, 9, 63. [CrossRef]

66. Kwenin, D.O.; Muathe, S.; Nzulwa, R. The influence of employee rewards, human resource policies and job satisfaction on the retention of employees in Vodafone Ghana Limited. Eur. J. Bus. Manag. 2013, 5, 13-20.

67. Chrintr, P. Perceived organizational culture, stress and job satisfaction affecting on hotel employee retention: A comparison study between management and operational employees. Employ. Relat. Rec. 2010, 10, 64-74. 
68. Ahmad, K.Z. The mediating effect of person-environment fit on the relationship between organizational culture and job satisfaction. Int. J. Psychol. Stud. 2012, 4, 91. [CrossRef]

69. Baker, G.P.; Jensen, M.C.; Murphy, K.J. Compaensation and incentives: Practice vs. theory. J. Financ. 1988, 43, 593-616. [CrossRef]

70. Griffeth, R.W.; Hom, P.W.; Gaertner, S. A meta-analysis of antecedents and correlates of employee turnover: Update, moderator tests and research implications for the next millennium. J. Manag. 2000, 26, 463-488. [CrossRef]

71. Hytter, A. Retention strategies in France and Sweden. Ir. J. Manag. 2007, 28, 59-79.

72. Eisenberger, R.; Stinglhamber, F.; Vandenberghe, C.; Sucharski, I.L.; Rhoades, L. Perceived supervisor support: Contributions to perceived organizational support and employee retention. J. Appl. Psychol. 2002, 87, 565. [CrossRef] [PubMed]

73. Hills, A. Succession planning-Or smart talent management? Ind. Commer. Train. 2009, 41, 3-8. [CrossRef]

74. Kaplan, D.M.; Wiley, J.W.; Maertz, C.P., Jr. The role of calculative attachment in the relationship between diversity climate and retention. Hum. Resour. Manag. 2011, 50, 271-287. [CrossRef]

75. Ansari, K.R.; Bijalwan, P. Team effectiveness: A relational approach with employee retention. Metamorphosis 2017, 16, 115-121. [CrossRef]

76. Arasanmi, C.N.; Krishna, A. Employer branding: Perceived organizational support and employee retention-The mediating role of organizational commitment. Ind. Commer. Train. 2019, 51, 174-183. [CrossRef]

77. Miller, J.G.; Wheeler, K.G. Unraveling the mysteries of gender differences in intentions to leave the organization. J. Organ. Behav. 1992, 13, 465-478. [CrossRef]

78. Arnold, E. Managing human resources to improve employee retention. Health Care Manag. 2005, 24, 132-140. [CrossRef] [PubMed]

79. Walsh, K.; Taylor, M.S. Developing in-house careers and retaining management talent: What hospitality professionals want from their jobs. Cornell Hotel and Restaurant. Adm. Q. 2007, 48, 163-182.

80. Al-Hajri, S.A. Employee Retention in light of Green HRM practices through the Intervening role of Work Engagement. Ann. Contemp. Dev. Manag. HR (ACDMHR) 2020, 2, 10-19. [CrossRef]

81. Likhitkar, P.; Verma, P. Impact of green HRM practices on organization sustainability and employee retention. Int. J. Innov. Res. Multidiscip. Field 2017, 3, 152-157.

82. Messmer, M. Four keys to improved staff retention. Strateg. Financ. 2006, 13-15. Available online: https://go.gale.com/ ps /i.do?id=GALE\%7CA152888878\&sid=googleScholar\&v=2.1\&it=r\&linkaccess=abs\&issn=1524833X\&p=AONE\&sw=w\& userGroupName=anon\%7E935c66b2 (accessed on 12 December 2021).

83. Chytiri, A.; Filippaios, F.; Chytiris, L. Hotel recruitment and selection practices: The case of the Greek hotel industry. Int. J. Organ. Leadersh. 2018, 7, 324-339. [CrossRef]

84. Kumar, P.; Gupta, S.K. A study of human resource management practices with reference to employees' recruitment and selection in travel trade enterprises in Garhwal region of Uttarakhand. Avahan A J. Hosp. Tour. 2017, 5, 126-133. 